\title{
Research on High-Pressure Hydrochloric Acid Leaching of Scandium, Aluminum and Other Valuable Components from the Non-Magnetic Tailings Obtained from Red Mud after Iron Removal
}

\author{
Dmitry Zinoveev ${ }^{1, *(\mathbb{D})}$, Pavel Grudinsky ${ }^{1}$ (D) Ekaterina Zhiltsova ${ }^{1,2}$, Darya Grigoreva ${ }^{1}$ (D) Anton Volkov ${ }^{3}$, \\ Valery Dyubanov ${ }^{1}$ and Alexander Petelin ${ }^{4}$
}

Citation: Zinoveev, D.; Grudinsky, P.; Zhiltsova, E.; Grigoreva, D.; Volkov, A.; Dyubanov, V.; Petelin, A. Research on High-Pressure Hydrochloric Acid Leaching of Scandium, Aluminum and Other Valuable Components from the Non-Magnetic Tailings Obtained from Red Mud after Iron Removal. Metals 2021, 11, 469. https://doi.org/10.3390/met11030469

Academic Editors: Fernando Castro and Anna Kaksonen

Received: 30 January 2021

Accepted: 8 March 2021

Published: 12 March 2021

Publisher's Note: MDPI stays neutral with regard to jurisdictional claims in published maps and institutional affiliations.

Copyright: (c) 2021 by the authors. Licensee MDPI, Basel, Switzerland. This article is an open access article distributed under the terms and conditions of the Creative Commons Attribution (CC BY) license (https:/ / creativecommons.org/licenses/by/ $4.0 /)$.
1 Laboratory of Physical Chemistry and Technology of Iron Ore Processing, A.A. Baikov Institute of Metallurgy and Materials Science, Russian Academy of Science, 49 Leninsky Prosp., 119334 Moscow, Russia; pgrudinskiy@imet.ac.ru (P.G.); ekaterinazhiltsova@yandex.ru (E.Z.); dashagrgrv121@gmail.com (D.G.); vdyubanov@imet.ac.ru (V.D.)

2 Faculty of Biotechnology and Industrial Ecology, D. Mendeleev University of Chemical Technology of Russia, 9 Miusskaya Square, 125047 Moscow, Russia

3 Laboratory of Complex Chemical Research, N.P. Lyakishev Scientific Center for Complex Processing of Raw Materials, I. P. Bardin Central Research Institute of Ferrous Metallurgy, 23/9 bdg. 2, Radio Str., 105005 Moscow, Russia; rhenium@list.ru

4 Department of Energy-Efficient and Resource-Saving Industrial Technologies, National University of Science \& Technology (MISIS), 4 Leninsky Prosp., 119049 Moscow, Russia; sasha@misis.ru

* Correspondence: dzinoveev@imet.ac.ru; Tel.: +7-499-135-9449

Abstract: Red mud is a hazardous waste of the alumina industry that contains high amounts of iron, aluminum, titanium and rare-earth elements (REEs). One of the promising methods for the extraction of iron from red mud is carbothermic reduction with the addition of sodium salts. This research focuses on the process of hydrochloric high-pressure acid leaching using 10 to $20 \% \mathrm{HCl}$ of two samples of non-magnetic tailings obtained by $60 \mathrm{~min}$ carbothermic roasting of red mud at $1300{ }^{\circ} \mathrm{C}$ and the mixture of $84.6 \mathrm{wt} . \%$ of red mud and $15.4 \mathrm{wt} . \% \mathrm{Na}_{2} \mathrm{SO}_{4}$ at $1150{ }^{\circ} \mathrm{C}$, respectively, with subsequent magnetic separation of metallic iron. The influence of temperature, leaching duration, solid-to-liquid-ratio and acid concentration on the dissolution behavior of $\mathrm{Al}, \mathrm{Ti}, \mathrm{Mg}, \mathrm{Ca}, \mathrm{Si}, \mathrm{Fe}, \mathrm{Na}$, $\mathrm{La}, \mathrm{Ce}, \mathrm{Pr}, \mathrm{Nd}, \mathrm{Sc}, \mathrm{Zr}$ was studied. Based on the investigation of the obtained residues, a mechanism for passing valuable elements into the solution was proposed. It has shown that $90 \% \mathrm{Al}, 91 \% \mathrm{Sc}$ and above $80 \%$ of other REEs can be dissolved under optimal conditions; Ti can be extracted into the solution or the residue depending on the leaching temperature and acid concentration. Based on the research results, novel flowsheets for red mud treatment were developed.

Keywords: red mud; bauxite residue; reduction roasting; sodium sulfate; magnetic separation; alumina; high pressure acid leaching; hydrochloric acid; recycling; utilization

\section{Introduction}

Red mud is a solid waste generated during the extraction of alumina from bauxite ores by the Bayer method [1]. At the present time, the main treatment methods for red mud include stockpiling by damming, direct sea-fill, and sea-fill after neutralization [2]. Globally, about 4 billion tons of red mud are currently stored [3,4]. The lack of efficient processing technologies is the main reason why red mud is out of use and accumulated in special sludge storage facilities, which have an adverse impact on the environment and have even led to technogenic catastrophe [3]. It has found that red mud is proved to be a promising material for obtaining coagulants and can be used as an adsorbent for heavy metals in wastewater [5]; it can also be utilized in a wide range of catalytic applications [6], as well as for a production of various building materials [7]. 
The typical contents of valuable components in red mud such as $\mathrm{Ti}, \mathrm{Si}, \mathrm{Fe}, \mathrm{Na}$ and $\mathrm{Al}$ are 2 to $12 \%, 1$ to $9 \%, 14$ to $45 \%, 1$ to $6 \%$ and 5 to $14 \%$, respectively [8]. Moreover, red mud also contains a small proportion of REEs in the range of 0.05 to $0.17 \%$ [9]. It is important to note that the Sc content in red mud is in the range of 0.013 to $0.039 \%$ [10], which is quite significant. The actual composition of red mud depends on the bauxite mineralogy and different technological parameters of the Bayer process [11]. The iron content in red mud is comparable with poor iron ore [12], which is an important driver for research on the processing of red mud.

Many processes have been proposed for the recovery of valuable components from red mud $[9,13,14]$. In the last years, there has been a high interest for the selective recovery of scandium $[10,15,16]$. Direct leaching processes using different lixiviants such as alkaline solutions [17,18], hydrochloric and sulfuric acids [19-25], organic acids [26,27] and ionic liquids [28,29] have been thoroughly investigated. However, direct leaching methods are either non-selective or ineffective for the extraction of titanium and REEs.

The high content of iron in red mud is the main hindering factor for the extraction of REEs from the solutions obtained by red mud acid leaching [29,30]. For this reason, the most promising way to comprehensively recycle red mud is by using combined pyroand hydrometallurgical methods with the recovery of iron by pyrometallurgical methods followed by the leaching of valuable components from the iron-depleted red mud [31]. The main pyrometallurgical ways for iron recovery from red mud are reduction smelting and carbothermic roasting with the subsequent magnetic separation of reduced iron. The reduction smelting either requires a high temperature and uses different fluxes such as $\mathrm{CaO}[32], \mathrm{CaO}-\mathrm{SiO}_{2}$ mixtures $[30,33,34], \mathrm{Al}_{2} \mathrm{O}_{3}$ [35], or needs the preliminary extraction of alumina [36] for the obtaining of slags with a low viscosity and melting temperature. The more favorable way is carbothermic roasting followed by magnetic separation, which is favorable due to its lower energy consumption compared with reduction smelting. Many studies [37-42] have shown that direct carbothermic roasting of red mud with different additions followed by magnetic separation results in the obtaining of iron concentrates with about $95 \%$ of iron content at temperatures below $1200{ }^{\circ} \mathrm{C}$.

There are several studies describing the leaching of valuable elements from tailings obtained by the carbothermic roasting of red mud with alkaline salts followed by magnetic separation. Such a two-step process followed by alumina extraction using alkaline leaching was proposed for red mud treatment $[43,44]$, but alkaline leaching of the tailings led to the recovery of only alumina and sodium without the extraction of other valuable elements. It has shown [45] that the addition of sodium salts such as $\mathrm{Na}_{2} \mathrm{CO}_{3}$ and $\mathrm{Na}_{2} \mathrm{SO}_{4}$ significantly improves the recovery of $\mathrm{Al}, \mathrm{Fe}, \mathrm{Ti}$ and $\mathrm{Si}$ from the tailings by sulfuric acid leaching at $30{ }^{\circ} \mathrm{C}$.

The dissolution of silicon from red mud during an acid leaching can lead to the formation of silica gel, which causes significant difficulties for the filtration of the leached solution [46], so different methods were proposed to avoid it. The comparative atmosphere leaching of the tailings by different inorganic acids, namely, hydrochloric, nitric, sulfuric, and phosphoric [47] has indicated that only phosphoric acid allows the selective removal of $\mathrm{SiO}_{2}$ with substantial enrichment of $\mathrm{Sc}_{2} \mathrm{O}_{3}$ and $\mathrm{TiO}_{2}$ in the residue. A suggested two-step process includes $\mathrm{SiO}_{2}$ extraction by phosphoric acid leaching followed by $\mathrm{Al}_{2} \mathrm{O}_{3}$ extraction from the residue by the leaching using sodium hydroxide. The other approaches, which allows silica gel formation to be avoided, are high-pressure acid leaching (HPAL) or using a high liquid-to-solid ratio [48]. The comparative study of the dissolution efficiency of the slags after red mud reduction smelting at atmosphere leaching and high-pressure leaching using $\mathrm{HCl}$ and $\mathrm{H}_{2} \mathrm{SO}_{4}$ have shown that high-pressure hydrochloric acid leaching allows for the extraction of more than $90 \% \mathrm{Al}$ and above $95 \% \mathrm{Y}, \mathrm{La}$, and $\mathrm{Nd}$, as well as up to $80 \%$ Sc with the co-dissolution of Si and Ti below 5\% [30]. The use of hydrochloric acid for HPAL for the aluminum extraction in different high-silica materials, e.g., coal ash [49], and boehmite-kaolinite bauxites [50,51], resulted in higher aluminum extraction compared with other mineral acids [52]. 
Thus, a promising way for the extraction of valuable components from red mud is the reduction roasting with obtaining of magnetic iron concentrate and non-magnetic tailings enriched in aluminum, titanium and REEs followed by the treatment of the tailings by high-pressure hydrochloric acid leaching.

In this paper, we study hydrochloric acid leaching of two different kinds of the tailings after the carbothermic roasting and magnetic separation of red mud. The leaching behavior of major elements ( $\mathrm{Al}, \mathrm{Ti}, \mathrm{Ca}, \mathrm{Si}, \mathrm{Fe}, \mathrm{Na}, \mathrm{Mg}$ ) and minor elements (Sc, Y, La, Ce, Nd, Pr, Zr) under atmosphere and high-pressure conditions were investigated. The most influencing factors on the leaching process were identified, and optimal leaching conditions were determined. The obtained solutions and the solid residues were characterized by different methods, so a leaching mechanism to extract valuable components was proposed. Two flowsheets for the processing of the both non-magnetic tailings were developed.

\section{Materials and Methods}

\subsection{Raw Materials}

Two samples of non-magnetic tailings were derived by reduction roasting-a magnetic separation process of red mud (RM) from the Bogoslovsky Aluminium Plant (Russian Federation, Krasnoturyinsk, $59.84^{\circ} \mathrm{N}, 60.19^{\circ} \mathrm{E}$ ) at optimal conditions according to our previous work [53]. The first sample codenamed as without addition tailings (WAT) was obtained by the reduction roasting of RM at $130{ }^{\circ} \mathrm{C}$ for $1 \mathrm{~h}$. The second sample codenamed as sodium sulfate addition tailings (SSAT) was obtained by reduction roasting of the mixture of 84.6 wt. $\% \mathrm{RM}$ and $15.4 \mathrm{wt} \% \mathrm{Na}_{2} \mathrm{SO}_{4}$ at $1150{ }^{\circ} \mathrm{C}$ for $3 \mathrm{~h}$. Both the roasted samples were ground, screened through a 300-mesh sieve, and magnetically separated using a wet method by the Davis tube XCGS-50 (Shaoxing Weibang Mining Machinery Manufacturing Co., Ltd., Zhejiang, China) at magnetic field intensity of 0.1 T. Table 1 demonstrates the chemical compositions including iron content of the RM, WAT, and SSAT samples.

Table 1. Chemical composition of the samples (wt.\% or $\mathrm{mg} / \mathrm{kg}$ ).

\begin{tabular}{ccccc}
\hline Element & Unit & RM & WAT & SSAT \\
\hline $\mathrm{Fe}$ & wt. $\%$ & 34.8 & 2.60 & 4.50 \\
$\mathrm{Si}$ & $\mathrm{wt} \%$ & 4.07 & 10.1 & 8.37 \\
$\mathrm{Al}$ & $\mathrm{wt} \%$ & 6.76 & 16.7 & 13.10 \\
$\mathrm{Ti}$ & $\mathrm{wt} \%$ & 6.80 & 16.2 & 5.50 \\
$\mathrm{Ca}$ & $\mathrm{wt} \%$ & 6.62 & 1.59 & 10.56 \\
$\mathrm{Mg}$ & $\mathrm{wt} \%$ & 0.390 & 0.294 & 1.08 \\
$\mathrm{Mn}$ & $\mathrm{wt} \%$ & 0.200 & 1.24 & 0.225 \\
$\mathrm{Na}$ & $\mathrm{wt} \%$ & 0.0742 & 6.62 \\
$\mathrm{P}$ & $\mathrm{wt} \%$ & 0.45 & 0.440 & 0.0570 \\
$\mathrm{~S}$ & $\mathrm{wt} \%$ & 626 & 4.77 \\
$\mathrm{Zr}$ & $\mathrm{mg} / \mathrm{kg}$ & 252 & 340 & 486 \\
$\mathrm{Sc}$ & $\mathrm{mg} / \mathrm{kg}$ & 140 & 1100 & 260 \\
$\mathrm{Y}$ & $\mathrm{mg} / \mathrm{kg}$ & 460 & 760 & 950 \\
$\mathrm{Nd}$ & $\mathrm{mg} / \mathrm{kg}$ & 270 & 147 & 590 \\
$\mathrm{Pr}$ & $\mathrm{mg} / \mathrm{kg}$ & 60.0 & 655 & 127 \\
$\mathrm{Ce}$ & $\mathrm{mg} / \mathrm{kg}$ & 390 & 670 & 992 \\
$\mathrm{La}$ & $\mathrm{mg} / \mathrm{kg}$ & 290 & & 690 \\
\hline
\end{tabular}

As can be seen, the contents of $\mathrm{Al}_{2} \mathrm{O}_{3}, \mathrm{TiO}_{2}$, and REEs are significantly increased, but the Fe content was considerably decreased in the WAT and SSAT samples compared with the RM sample. The compositions of both the tailings are quite similar, but they are different in sulfur and sodium contents due to the addition of $\mathrm{Na}_{2} \mathrm{SO}_{4}$ for the SSAT sample in the roasting process. 
Figure 1 shows diffractograms of the WAT and SSAT samples with phase signs. The phase composition of the RM sample is in our previous paper [53]. The mineral compositions of the samples are quite different.

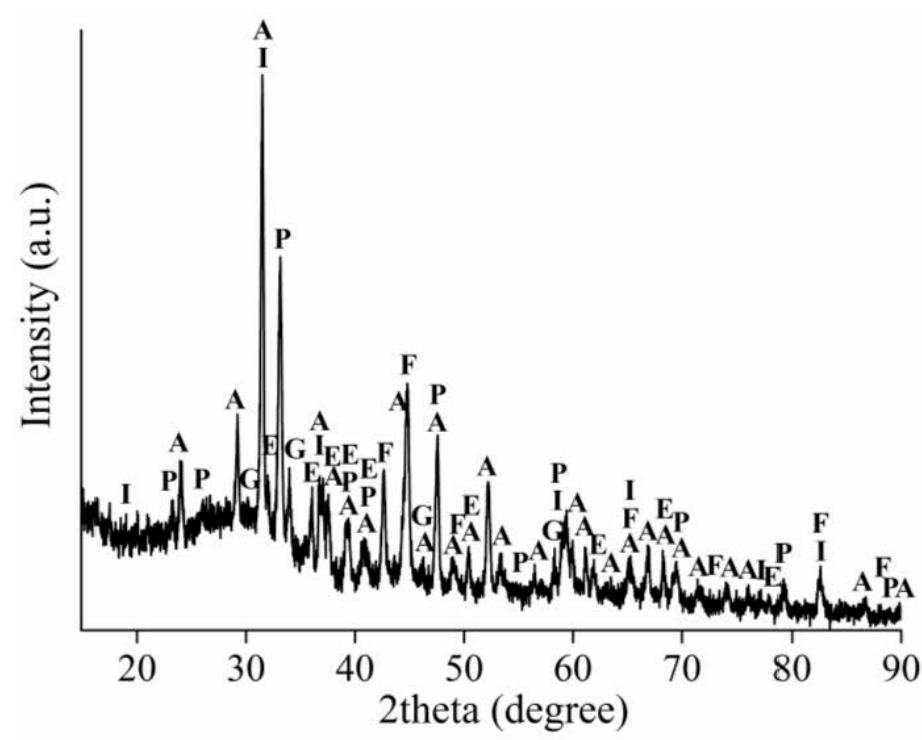

(a)

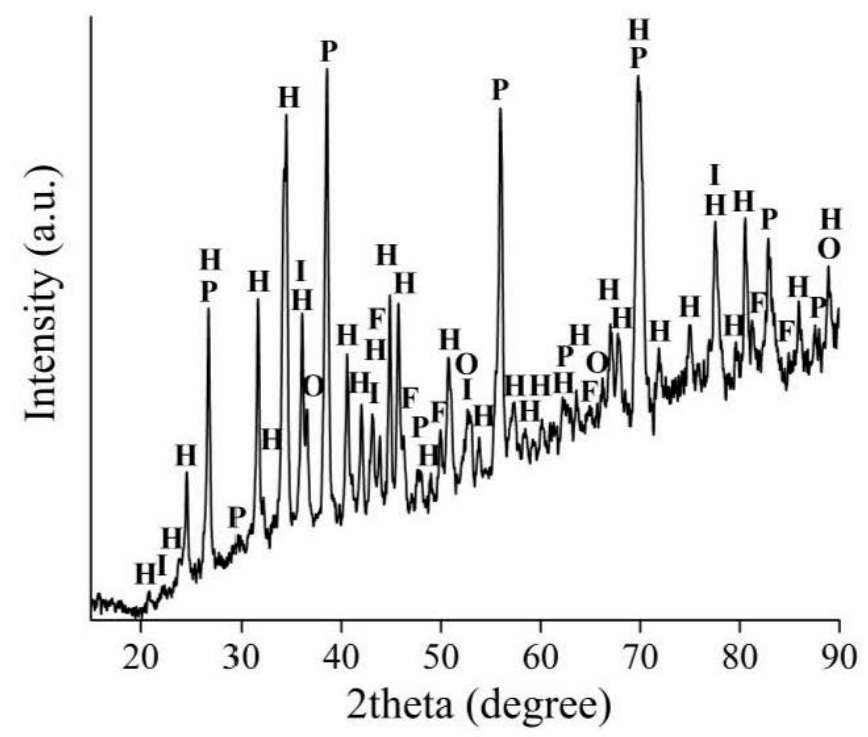

(b)

Figure 1. The XRD pattern of the WAT sample obtained using $\mathrm{Cu}-\mathrm{K}_{\alpha}$ radiation (a) and the SSAT sample obtained using $\mathrm{Co}-\mathrm{K}_{\alpha}$ radiation $(\mathbf{b})$, where $\mathrm{A}-\mathrm{Ca}_{2} \mathrm{Al}_{2} \mathrm{SiO}_{7} ; \mathrm{P}-\mathrm{CaTiO}{ }_{3} ; \mathrm{F}-\mathrm{Fe} ; \mathrm{G}-\mathrm{Ca}_{3} \mathrm{Al}_{2} \mathrm{Si}_{3} \mathrm{O}_{12}$; $\mathrm{E}-\mathrm{Mg}_{3} \mathrm{Al}_{2} \mathrm{Si}_{3} \mathrm{O}_{12} ; \mathrm{I}-\mathrm{MgAl}_{2} \mathrm{O}_{4} ; \mathrm{H}-\mathrm{NaAlSiO}_{4} ; \mathrm{O}-\mathrm{CaS}$.

The major phases of the WAT sample are $\mathrm{Ca}_{2} \mathrm{Al}_{2} \mathrm{SiO}_{7}$ (gehlenite), $\mathrm{CaTiO}_{3}$ (perovskite), $\mathrm{Ca}_{3} \mathrm{Al}_{2} \mathrm{Si}_{3} \mathrm{O}_{12}$ (grossular). Furthermore, it contains small amounts of $\mathrm{Mg}_{3} \mathrm{Al}_{2} \mathrm{Si}_{3} \mathrm{O}_{12}$ (pyrope), $\mathrm{MgAl}_{2} \mathrm{O}_{4}$ (magnesium aluminum oxide), and $\mathrm{Fe}$ (iron). The major phases of the SSAT sample are $\mathrm{NaAlSiO}_{4}$ (nepheline) and CaS (oldhamite), which were formed by chemical reactions between $\mathrm{Na}_{2} \mathrm{SO}_{4}$ and calcium-aluminum-silicon oxides during the carbothermic roasting of red mud [53]. It should be noted that there is an absence of gehlenite and grossular in the SSAT compared to the WAT, as well as a similarity of other minerals to the WAT sample. 


\subsection{Experimental Procedure}

The chemical composition of the tailings and solid residues after the leaching were analyzed after an appropriate digestion using an inductively coupled plasma atomic emission spectrometer (ICP AES) Vista Pro (Varian Optical Spectroscopy Instr., Mulgrave, Australia). The samples for the analysis of Si were fused at $950{ }^{\circ} \mathrm{C}$ in the presence of soda and boric acid, then leached using $1 \mathrm{~N} \mathrm{HCl}$. The samples for ICP AES analysis of other elements were digested by a mixture of concentrated hydrofluoric, sulfuric and nitric acids; if it was necessary, the filtered residue was also fused at $950{ }^{\circ} \mathrm{C}$ in the presence of soda and boric acid and leached using $1 \mathrm{~N} \mathrm{HCl}$. Two duplicate samples were digested; three analyses by the ICP AES device were carried out for all the digested samples.

Additionally, the tailings and the solid residues were analyzed by X-ray fluorescence spectrometer (XRF) ARL QUANT'X (Thermo Fisher Scientific, Ekublens, Switzerland) and AXIOSmax Advanced (PANalytical, Almelo, The Netherlands), respectively. The mother liquors and washings were analyzed by an inductively coupled plasma atomic emission spectrometer (ICP-MS) Perkin-Elmer Sciex ELAN 6100 DRC (PerkinElmer Inc., Waltham, MA, USA) and ICP AES Optima 3300RL (PerkinElmer Inc., Waltham, MA, USA). X-ray diffraction patterns (XRD) were obtained by diffractometers Difrey (JSC Scientific Instruments, Saint-Petersburg, Russian Federation) using Co- $\mathrm{K}_{\alpha}$ radiation or ARL X'tra diffractometer (Thermo Fisher Scientific, Ekublens, Switzerland) using $\mathrm{Cu}-\mathrm{K}_{\alpha}$ radiation with their subsequent processing by the Match! software (Crystal Impact, Bonn, Germany) [54] using Crystallography Open Database.

The tailings were preliminary dried at $110{ }^{\circ} \mathrm{C}$ for $2 \mathrm{~h}$ and then leached using a laboratory autoclave P2004 (Shanghai Jieang Instrument Co., Shanghai, China) in $25 \mathrm{~mL}$ stainless steel pots with teflon inserts at a temperature in the range of 50 to $210^{\circ} \mathrm{C}$ at a stirring speed of $350 \mathrm{rpm}$ and duration time of 30 to $90 \mathrm{~min}$. Hydrochloric acid with a concentration in the range of 10 to $20 \%$ was used for the leaching; the solid-to-liquid ratios (S:L) used were 1:5.5, 1:11, 1:16.5. As a result of the leaching, a mother liquor was obtained by vacuum filtration. The solid residue obtained by the filtration was washed with distilled water and dried at $110^{\circ} \mathrm{C}$ in an air furnace for $2 \mathrm{~h}$.

The recovery degree of major and minor elements was calculated using following equations, respectively:

$$
\begin{gathered}
\% \varepsilon=100-\left(m_{r} \times \% M j E_{r}\right) /\left(m_{0} \times \% M j E_{0}\right) \times 100, \\
\% \varepsilon=\left(\alpha \times V_{\text {liq }}+\beta \times V_{\text {water }}\right) /\left(m_{0} \times \% M n E_{0}\right) \times 100,
\end{gathered}
$$

where $\varepsilon$-element recovery degree, $\% ; m_{r}$-mass of the solid residue, g; $m_{0}$-mass of the tailings, g; $\% M j E_{0}$ and $\% M j E_{r}$ - content of a major element in tailings and in the solid residue, respectively, $\%$; $\% M n E_{0}$ - content of a minor element in the tailings, $\%$; $\alpha$-content of an element in mother liquor, g/L; $V_{\text {liq }}$-volume of mother liquor, $1 ; \beta$-content of an element in washing distilled water, $\mathrm{g} / \mathrm{L} ; V_{\text {water }}$-volume of washing distilled water, 1 .

The samples before and after leaching were placed onto the carbon tape and analyzed using scanning electron microscope (SEM) VEGA 3SB (Tescan, Brno, Czech Republic) equipped by energy-dispersive X-ray analyzer (EDX) INCA SDD X-MAX (Oxford Instruments, Abingdon, UK).

\section{Results}

\subsection{HPAL Experiments with the Variation of Leaching Temperature and $\mathrm{HCl}$ Concentration 3.1.1. HPAL for the WAT Sample}

Figure 2 demonstrates the influence of the leaching temperature on the recovery degree of major elements for the WAT sample. A significant simultaneous dissolution of aluminum, iron, calcium, magnesium and sodium for both the acid concentration of $10 \%$ and $20 \%$ were discovered. An increase of temperature from 70 to $170{ }^{\circ} \mathrm{C}$ led to a growth of the aluminum extraction degree from 74 to $91 \%$ for $10 \% \mathrm{HCl}$, while a temperature rise 
from 50 to $210{ }^{\circ} \mathrm{C}$ with the application of $20 \% \mathrm{HCl}$ resulted in an increase of the aluminum recovery degree from 81 to $98 \%$.
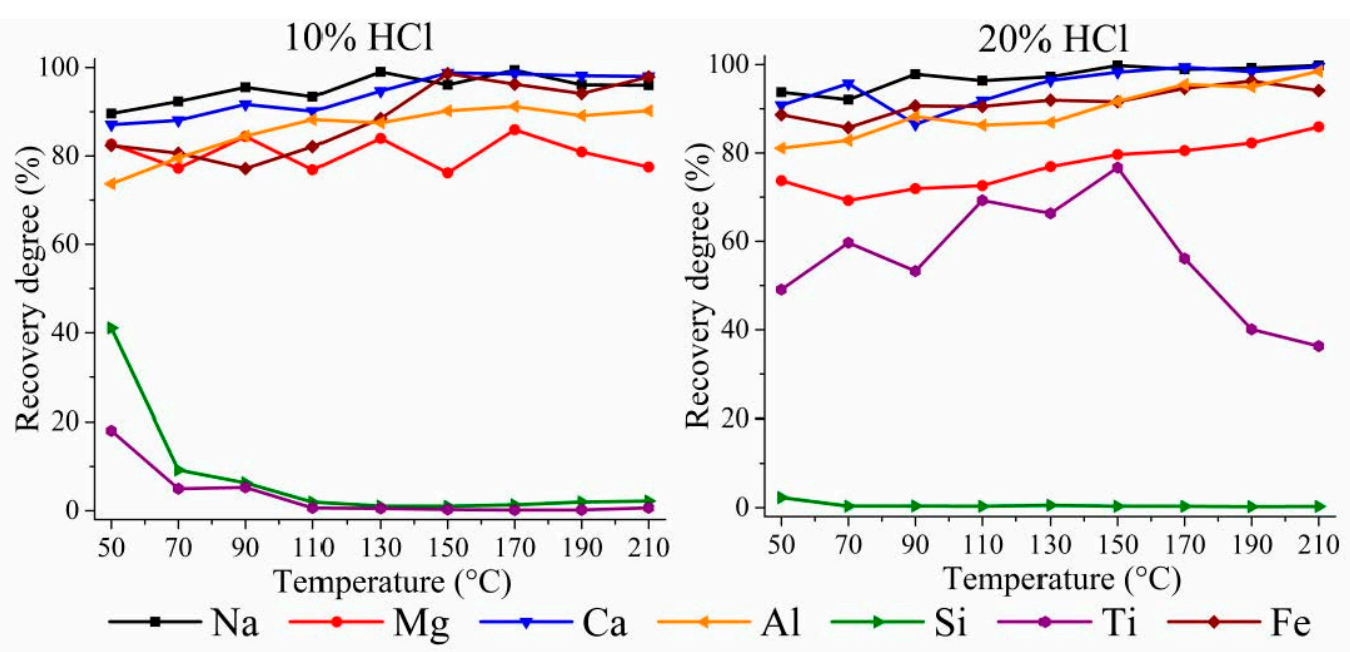

Figure 2. The effect of the temperature on recovery degree of the major elements for the leaching of the WAT sample using $10 \%$ and $20 \% \mathrm{HCl}$ at $\mathrm{S}: \mathrm{L}$ ratio $=1: 11$ for $60 \mathrm{~min}$.

Silicon dissolution degree was $41 \%$ at $50{ }^{\circ} \mathrm{C}$ for diluted acid, and it decreased to less than $2 \%$ with an increase of leaching temperature above $100{ }^{\circ} \mathrm{C}$; an increase of acid concentration also led to a similarly low dissolution of silicon. These results can be explained by significant retardation of silica hydration with a HPAL temperature rise due to water released as vapor, so a partially hydrated metal reacts with hydrochloric acid to silica form. Therefore, the use of HPAL allows silica gel formation to be avoided. The process can be described by the following equation [30,55]:

$$
\mathrm{M}_{2} \mathrm{SiO}_{4(\mathrm{~s})}+4 \mathrm{HCl}_{(\mathrm{l})}+(4 n-2) \mathrm{H}_{2} \mathrm{O}_{(\mathrm{l})}=2 \mathrm{MCl}_{2} n \mathrm{H}_{2} \mathrm{O}_{(\mathrm{l})}+\mathrm{SiO}_{2 \text { (filterable) }}
$$

The leaching behavior of titanium is quite different for $10 \%$ and $20 \%$ acid concentration. The recovery degree of titanium for diluted acid is $18 \%$ at $50{ }^{\circ} \mathrm{C}$; it decreases to less than $1 \%$ at temperatures above $100{ }^{\circ} \mathrm{C}$. In contrast, the dissolution degree of titanium at $50^{\circ} \mathrm{C}$ is $49 \%$ for concentrated acid; it increases to $77 \%$ with HPAL temperature rising up to $150{ }^{\circ} \mathrm{C}$, then decreases to $36 \%$. These results agree well with previously reported data [56,57], where perovskite is proved to be highly soluble in concentrated hydrochloric acid and poorly soluble in diluted acid. Hence, the use of high-pressure diluted hydrochloric acid leaching allows to separate selectively titanium and silicon from the other elements.

Figure 3 shows the influence of leaching temperature on the extraction degree of minor elements.

As can be seen, for both 10 and $20 \% \mathrm{HCl}$ the dissolution degrees of $\mathrm{La}, \mathrm{Ce}, \mathrm{Pr}, \mathrm{Nd}$ are very similar, but the dissolution behavior of $\mathrm{Sc}$ and $\mathrm{Y}$ is rather different; it is in agreement with the results of other researchers [58]. The recovery degrees of all REEs were near $40 \%$ for both the acid concentrations at $50{ }^{\circ} \mathrm{C}$; they increase significantly with temperature rising. REE extraction degrees have a peak with the values of more than $75 \%$ for $10 \% \mathrm{HCl}$ at the temperatures above $150{ }^{\circ} \mathrm{C}$. These results are also in accordance with [58], where a significant influence of the temperature on the leaching of REEs from iron-removed red mud was noted. There are a few differences between REE leaching using the diluted and concentrated acids. The REE extraction degree for $10 \% \mathrm{HCl}$ starts to increase dramatically at temperatures over $110^{\circ} \mathrm{C}$, and for $20 \% \mathrm{HCl}$ such an abrupt jump occurs above $90{ }^{\circ} \mathrm{C}$. The dissolution degree of Sc is near 80 to $90 \%$ at the low temperatures for the concentrated acid unlike 50 to $60 \%$ for the diluted acid. However, a rise of the temperature up to $150{ }^{\circ} \mathrm{C}$ and above using the diluted acid led to an achievement of a plateau at a level of 83 to $91 \%$, 
while using of the concentrated acid enabled to achieve the best extraction degrees of 96 to $97 \%$ in the range of 170 to $210^{\circ} \mathrm{C}$.

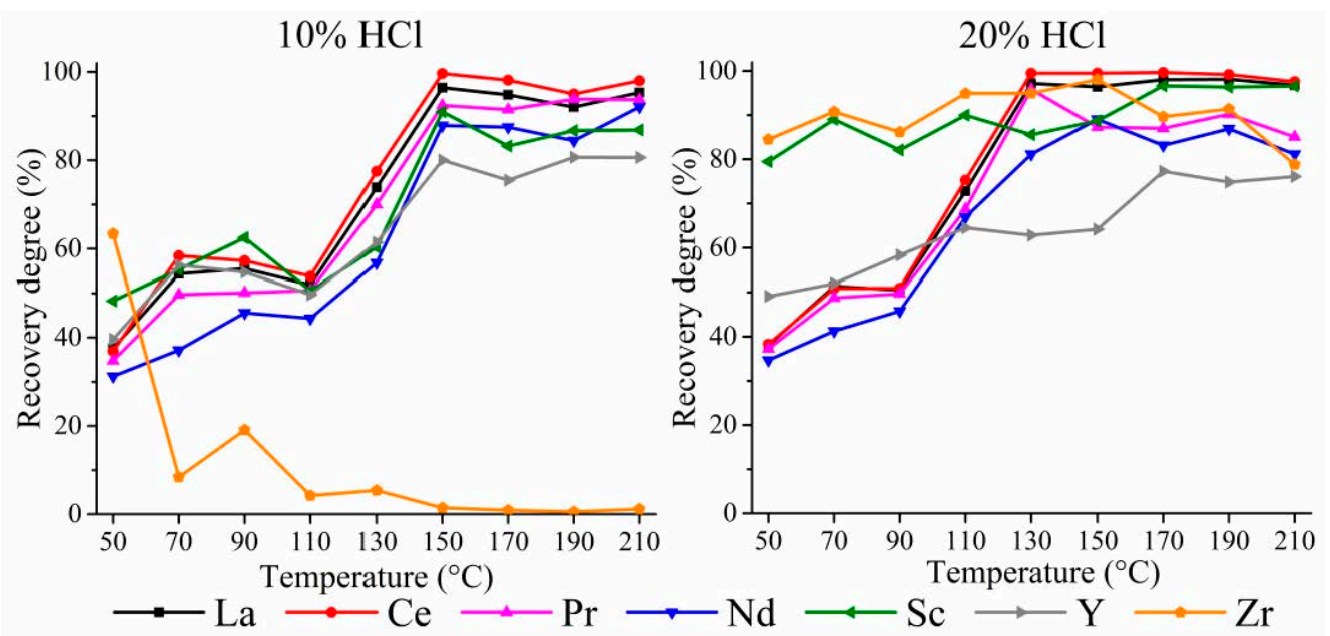

Figure 3. The effect of the temperature on recovery degree of the minor elements for the leaching of the WAT sample using $10 \%$ and $20 \% \mathrm{HCl}$ at $\mathrm{S}: \mathrm{L}$ ratio $=1: 11$ for $60 \mathrm{~min}$.

A zirconium behavior is considerably different compared with the other minor elements. The application of $10 \% \mathrm{HCl}$ at the temperature range of 110 to $210{ }^{\circ} \mathrm{C}$ resulted in the recovery degrees of $\mathrm{Zr}$ below $5 \%$, while the application of $20 \% \mathrm{HCl}$ at the same range led to 78 to $95 \% \mathrm{Zr}$ extraction. Therefore, either dissolution or retention in the residue can be considered for $\mathrm{Zr}$ recovery in the case of its economic feasibility. It should be noted that the behavior of $\mathrm{Zr}$ correlates with Ti qualitatively but differs quantitatively; this is probably because of the similarity of their properties due to their presence in the same subgroup of the periodic table.

\subsubsection{HPAL for the SSAT Sample}

The leaching of the SSAT sample was performed starting with $90{ }^{\circ} \mathrm{C}$ to avoid a substantial silicon dissolution at temperatures below. Figure 4 depicts the effect of the temperature and the acid concentration on the extraction degree of the major elements for the SSAT sample.
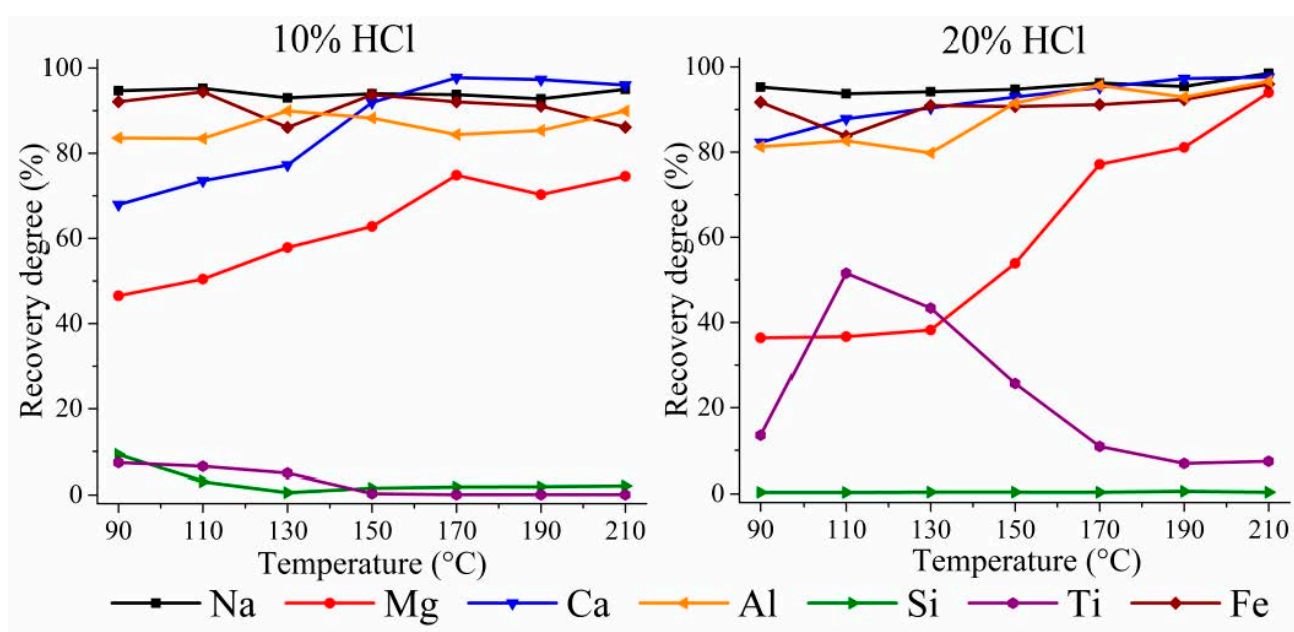

Figure 4. The effect of the temperature on the recovery degree of the major elements for the leaching of the SSAT sample using $10 \%$ and $20 \% \mathrm{HCl}$ at S:L ratio $=1: 11$ for $60 \mathrm{~min}$. 
The curves of $\mathrm{Fe}, \mathrm{Al}, \mathrm{Na}, \mathrm{Ti}$, and $\mathrm{Si}$ are fairly similar to the ones obtained by the processing of the WAT sample, but a behavior of $\mathrm{Mg}$ and $\mathrm{Ca}$ is significantly different. As can be seen, the extraction degree of calcium for $10 \%$ acid concentration is $68 \%$ at $90{ }^{\circ} \mathrm{C}$, whereas for the WAT sample under similar conditions is more than $91 \%$ (Figure 2). The dissolution degree of calcium grows up with a temperature increase and becomes above $91 \%$ only at $150{ }^{\circ} \mathrm{C}$ for both 10 and $20 \%$ acid concentration. The magnesium recovery degree rises from 46 to $74 \%$ for the diluted acid and from 36 to $94 \%$ for the concentrated acid at the range of 90 to $170{ }^{\circ} \mathrm{C}$. The maximum recovery degree of magnesium for the SSAT sample is $94 \%$ at $210{ }^{\circ} \mathrm{C}$ and $20 \% \mathrm{HCl}$ concentration.

Figure 5 shows the effect of the temperature on the extraction degree of minor elements for the SSAT sample.
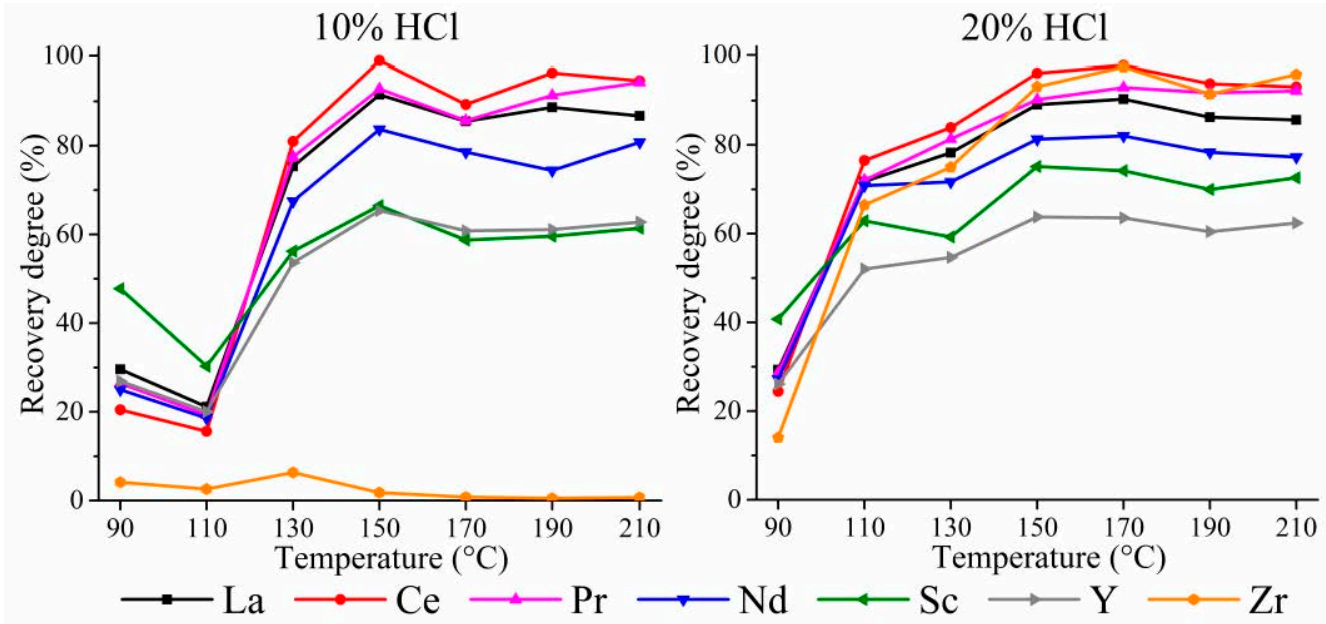

Figure 5. The effect of the temperature on the recovery degree of the minor elements for the SSAT sample using 10 and $20 \%$ $\mathrm{HCl}$ at S:L ratio $=1: 11$ for $60 \mathrm{~min}$.

As can be inferred from the plots, the main factor influencing the REE dissolution is the temperature for both the WAT and SSAT sample. An increase of acid concentration also leads to a rise of the REE recovery degree at low temperatures. The extraction degrees of La, $\mathrm{Ce}, \mathrm{Pr}$, and Nd are similar in the SSAT compared to the WAT sample, but the dissolution degrees of Sc and $\mathrm{Y}$ are lower. The maximum recovery degrees of Sc for the WAT sample were $91 \%$ for the diluted acid and $96 \%$ for concentrated acid, wherein they were only 66 and $75 \%$ for the SSAT sample, respectively. Other REEs also have a rather lower dissolution degree for the SSAT sample. A discrepancy in dissolution behavior of elements for the WAT and SSAT samples is likely due to a difference in chemical and phase compositions; we consider it below.

\subsection{The Analysis of the Solid Residues}

\subsubsection{The Solid Residues Obtained from the WAT Sample}

To determine the leaching mechanism, the XRD and SEM-EDX analyses of the solid residues after the leaching were performed.

Figure 6 demonstrates the elemental distribution of one of the residues obtained by HPAL of the WAT sample. It is clearly presented that the residue is a mixture of $\mathrm{SiO}_{2}$ and minerals containing aluminum, calcium and titanium.

Figure 7 presents the XRD patterns of the WAT residues obtained at various leaching temperatures using different $\mathrm{HCl}$ concentrations. The WAT sample contains four aluminum phases, namely, $\mathrm{Ca}_{2} \mathrm{Al}_{2} \mathrm{SiO}_{7}, \mathrm{Ca}_{3} \mathrm{Al}_{2} \mathrm{Si}_{3} \mathrm{O}_{12}, \mathrm{Mg}_{3} \mathrm{Al}_{2} \mathrm{Si}_{3} \mathrm{O}_{12}$, and $\mathrm{MgAl}_{2} \mathrm{O}_{4}$ (Figure 1), but the solid residues obtained by HPAL of the WAT sample using 10 and $20 \% \mathrm{HCl}$ contains no gehlenite, which fully dissolves at low leaching temperatures. These results correlate with the data of other researchers [59], where gehlenite passed into the solution in $1 \mathrm{M} \mathrm{HCl}$ after 
three-stage leaching during $2 \mathrm{~h}$ at room temperature. Aluminum in the solid residues is in the $\mathrm{Ca}_{3} \mathrm{Al}_{2} \mathrm{Si}_{3} \mathrm{O}_{12}, \mathrm{Mg}_{3} \mathrm{Al}_{2} \mathrm{Si}_{3} \mathrm{O}_{12}$, and $\mathrm{MgAl}_{2} \mathrm{O}_{4}$ phases that were incompletely dissolved at the experimental conditions. It has been shown [60] that grossular has a low solubility in the diluted hydrochloric acid; to decompose it fully, a high acid concentration and temperature over $130{ }^{\circ} \mathrm{C}$ are required (Figure 7). The magnesium aluminum oxide is also undissolved even at $190{ }^{\circ} \mathrm{C}$ and $20 \%$ acid concentration. $\mathrm{MgAl}_{2} \mathrm{O}_{4}$ is a hardly soluble phase that remains in the residue after sequential long-time treatment by 36 to $38 \% \mathrm{HCl}$ and $40 \% \mathrm{HF}$ [61]. Even high-pressure leaching by a strong $\mathrm{HCl}$ solution at $210{ }^{\circ} \mathrm{C}$ led to substantial but still incomplete dissolution of $\mathrm{MgAl}_{2} \mathrm{O}_{4}$ [62]. Therefore, full aluminum extraction requires a high temperature, a strong acid concentration and the use of HPAL.

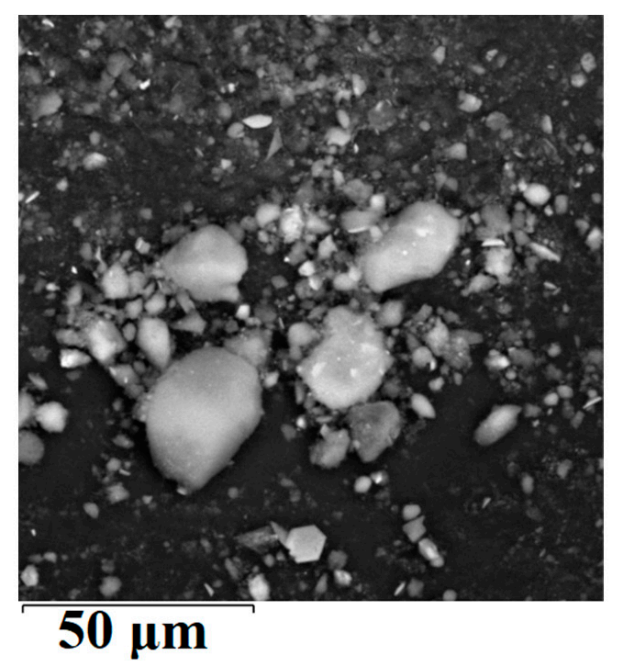

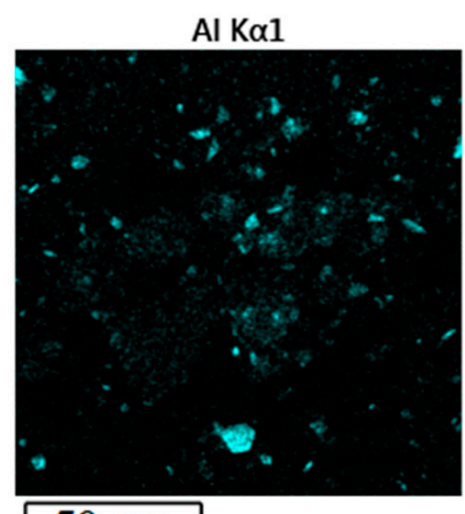

$50 \mu \mathrm{m}$
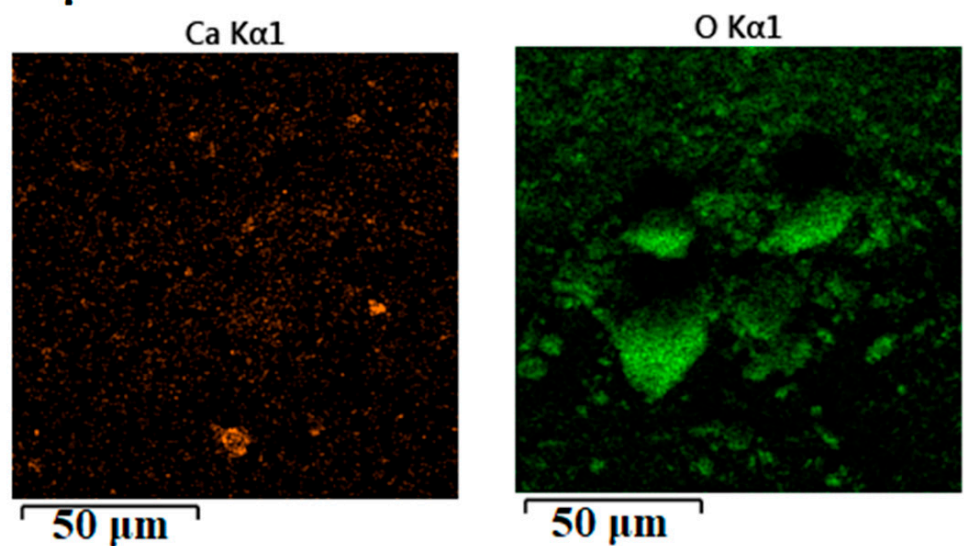

Si K $\alpha 1$
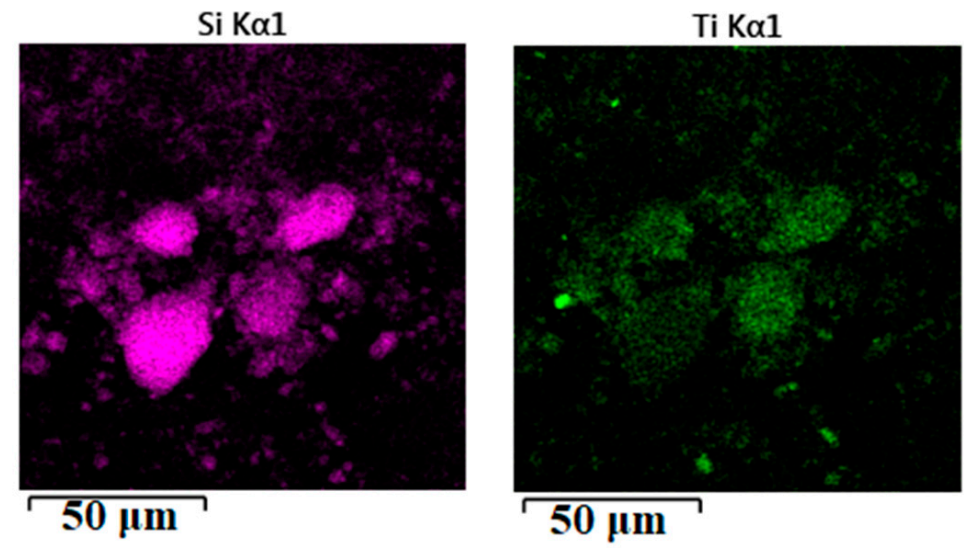

Figure 6. SEM images with the distribution of elements in the solid residue obtained by the leaching of the WAT sample using $10 \% \mathrm{HCl}$ at $150^{\circ} \mathrm{C}$ and $\mathrm{S}: \mathrm{L}=1: 11$ for $60 \mathrm{~min}$. 


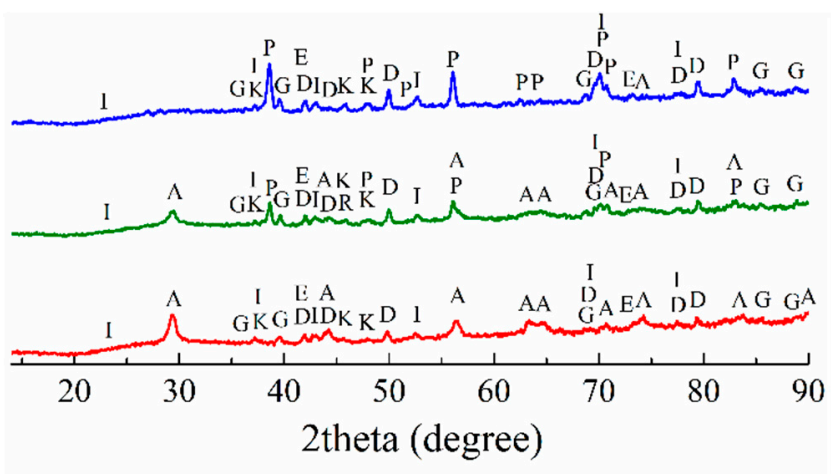

$-70^{\circ} \mathrm{C}-130^{\circ} \mathrm{C}-190^{\circ} \mathrm{C}$

(a)
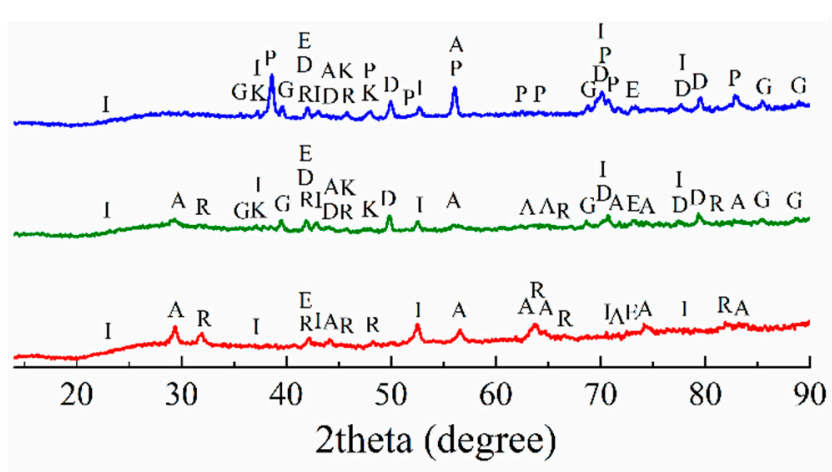

$-70^{\circ} \mathrm{C}-130^{\circ} \mathrm{C}-190^{\circ} \mathrm{C}$

(b)

Figure 7. The XRD patterns of the solid residues after leaching of WAT sample using $10 \%$ (a) and $20 \% \mathrm{HCl}(\mathbf{b})$, where $\mathrm{P}-$ $\mathrm{CaTiO}_{3} ; \mathrm{A}-\mathrm{TiO}_{2}$ (anatase); $\mathrm{R}-\mathrm{TiO}_{2}$ (rutile); $\mathrm{G}-\mathrm{Ca}_{3} \mathrm{Al}_{2} \mathrm{Si}_{3} \mathrm{O}_{12} ; \mathrm{K}-\mathrm{Ca}_{3} \mathrm{Al}_{2} \mathrm{Si}_{3}(\mathrm{OH})_{12} ; \mathrm{E}-\mathrm{Mg}_{3} \mathrm{Al}_{2} \mathrm{Si}_{3} \mathrm{O}_{12} ; \mathrm{D}-5 \mathrm{Al}_{2} \mathrm{O}_{3} \cdot \mathrm{H}_{2} \mathrm{O}$; $\mathrm{I}-\mathrm{MgAl}_{2} \mathrm{O}_{4}$.

The dissolution behavior of titanium is very different for the diluted and the concentrated acids. Figure 7a shows that perovskite exists in the solid residues after the treatment of the WAT sample by HPAL with $10 \% \mathrm{HCl}$ up to $130{ }^{\circ} \mathrm{C}$, and it was undetected in the residue at $190{ }^{\circ} \mathrm{C}$.

As follows from Figure $7 \mathrm{~b}$, the use of $20 \% \mathrm{HCl}$ led to the full dissolution of perovskite at temperatures lower than the use of $10 \% \mathrm{HCl}$, but the precipitation of titanium was incomplete. The titanium extraction degree increases with leaching temperature rising (Figure 2). A similar titanium behavior in hydrochloric acid solution also was reported earlier [30,62] that is likely owing to the titanium hydrolysis process [62]. The processes of dissolution and precipitation of titanium can be described as follows:

$$
\begin{gathered}
2 \mathrm{CaO} \cdot \mathrm{TiO}_{2(\mathrm{~s})}+8 \mathrm{HCl}_{(\mathrm{l})}=2 \mathrm{CaCl}_{2(\mathrm{l})}+\mathrm{TiCl}_{4(\mathrm{l})}+\mathrm{TiO}_{2(\mathrm{~s})} \downarrow+4 \mathrm{H}_{2} \mathrm{O}_{(\mathrm{l})}, \\
\mathrm{CaO} \cdot \mathrm{TiO}_{2(\mathrm{~s})}+4 \mathrm{HCl}_{(\mathrm{l})}=\mathrm{TiOCl}_{2(\mathrm{l})}+\mathrm{CaCl}_{2(\mathrm{l})}+2 \mathrm{H}_{2} \mathrm{O}_{(\mathrm{l})}, \\
\mathrm{TiOCl}_{2(\mathrm{l})}+(\mathrm{x}+1) \mathrm{H}_{2} \mathrm{O}_{(\mathrm{l})}=2 \mathrm{HCl}_{(\mathrm{l})}+\mathrm{TiO}_{2} \cdot \mathrm{xH}_{2} \mathrm{O}_{(\mathrm{s})} \downarrow
\end{gathered}
$$

Although the main part of aluminum passed into solution during HPAL, small peaks of aluminum-containing phase, $5 \mathrm{Al}_{2} \mathrm{O}_{3} \cdot \mathrm{H}_{2} \mathrm{O}$, were still detected in the residues obtained at 70 to $190{ }^{\circ} \mathrm{C}$ using $10 \% \mathrm{HCl}$ and at 70 to $130{ }^{\circ} \mathrm{C}$ using $20 \% \mathrm{HCl}$. Figure 8 and Table 2 also confirm the presence of this phase using SEM-EDX analyses. As reported by [63], $5 \mathrm{Al}_{2} \mathrm{O}_{3} \cdot \mathrm{H}_{2} \mathrm{O}$ may be formed only under hydrothermal conditions. It is an open question how this phase has been generated during the experiments, but its formation is an unambiguously adverse factor due to the decrease of the aluminum dissolution degree.

Table 2. Elemental composition (at.\%) of the sample point signed in Figure 8.

\begin{tabular}{cccccccc}
\hline Sign & Al & Si & Ti & Ca & Mg & Cl & O \\
\hline 1 & 21.6 & 5.20 & 2.30 & 1.60 & 1.40 & 0.200 & 67.6 \\
\hline
\end{tabular}

Table 3 shows that the residues obtained by HPAL using the diluted and the concentrated acids contain different amounts of $\mathrm{SiO}_{2}$ and $\mathrm{TiO}_{2}$, as well as a similar amount of $\mathrm{Al}_{2} \mathrm{O}_{3}$. The residue obtained by $\mathrm{HPAL}$ using $20 \% \mathrm{HCl}$ at $210{ }^{\circ} \mathrm{C}$ has a lower $\mathrm{Al}_{2} \mathrm{O}_{3}$ and $\mathrm{MgO}$ amount compared with the residues obtained at lower temperatures and acid concentration. These data substantiate the above-mentioned leaching mechanism for the WAT leaching. 


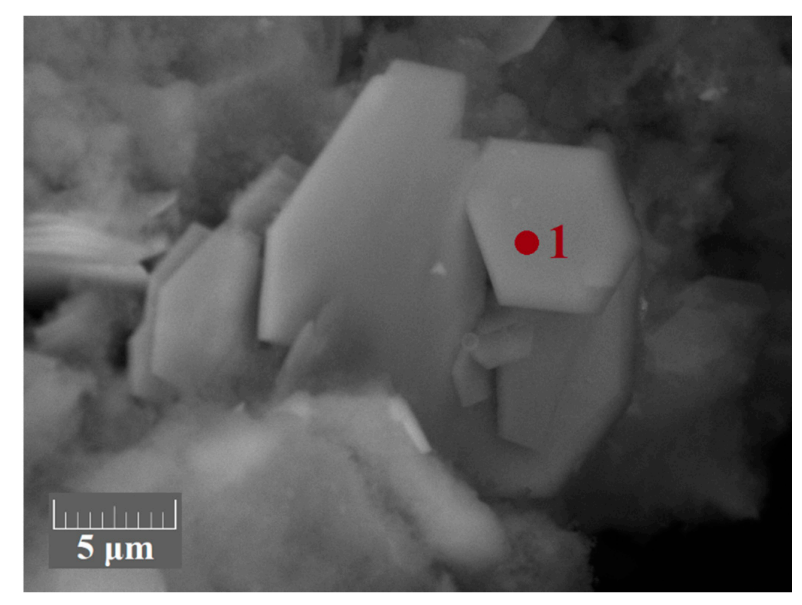

Figure 8. SEM image of an area in the solid residue obtained by leaching of the WAT sample using $10 \% \mathrm{HCl}$ at $150{ }^{\circ} \mathrm{C}$ and S:L ratio $=1: 11$ for $60 \mathrm{~min}$. The composition of the point 1 is given in Table 2 .

Table 3. Chemical composition of the solid residues obtained by the leaching of the WAT sample at $\mathrm{S}: \mathrm{L}$ ratio $=1: 11$ for $60 \mathrm{~min}$ (wt.\%).

\begin{tabular}{ccccccc}
\hline HPAL Conditions & Al & Ca & Mg & Si & Ti & S \\
\hline $10 \% \mathrm{HCl}, 190^{\circ} \mathrm{C}$ & 4.95 & 0.928 & 0.826 & 27.6 & 13.5 & 0.155 \\
$20 \% \mathrm{HCl}, 150^{\circ} \mathrm{C}$ & 4.48 & 1.02 & 1.05 & 33.5 & 5.78 & 0.244 \\
$20 \% \mathrm{HCl}, 210^{\circ} \mathrm{C}$ & 0.68 & 0.23 & 0.61 & 36.0 & 8.73 & 0.253 \\
\hline
\end{tabular}

Figure 3 demonstrates that REE dissolution is sharply increased at temperatures for both acid concentrations above 110 and $90{ }^{\circ} \mathrm{C}$, respectively; this is likely due to the dissolution of $\mathrm{CaTiO}_{3}$ (Figure 7). REEs can be associated with perovskite in the form of solid solution [64]. It was reported that $\mathrm{Sc}$ in the slag obtained after red mud reduction smelting is associated with $\mathrm{CaTiO}_{3}$ [30] and with $\mathrm{Ti}$ in the initial red mud [65]. It should be mentioned that $\mathrm{Sc}$ also can be partially associated with grossular [58].

In summary, it can be inferred that the leaching temperature of $150{ }^{\circ} \mathrm{C}$ and acid concentration of $10 \%$ are the optimal conditions for the WAT treatment that led to passing into solution of $91 \% \mathrm{Sc}$ and above $80 \%$ of other REEs and maintaining $\mathrm{TiO}_{2}$ and $\mathrm{SiO}_{2}$ in the residue. It should be noted that small aluminum losses with the residue are inevitable.

\subsubsection{The Solid Residues Obtained from the SSAT Sample}

Figure 9 shows the results of the SEM-EDX analysis of the residue obtained by HPAL of the SSAT sample using $10 \% \mathrm{HCl}$ at $170{ }^{\circ} \mathrm{C}$. One can see from the images that the SSAT residue, like the WAT sample, mainly consists of $\mathrm{SiO}_{2}$ and titanium oxide. Moreover, sulfur can be observed in the form of particular grains. It is noteworthy that the distribution of aluminum and magnesium correlates clearly point to the presence of $\mathrm{MgAl}_{2} \mathrm{O}_{4}$.

The generation of elemental sulfur during HPAL is probably due to the following mechanism. It is clear that calcium sulfide containing in the tailings interacts with hydrochloric acid forming hydrogen sulfide:

$$
\mathrm{CaS}_{(\mathrm{s})}+2 \mathrm{HCl}_{(\mathrm{l})}=\mathrm{CaCl}_{2(\mathrm{l})}+\mathrm{H}_{2} \mathrm{~S}_{(\mathrm{g})} .
$$

Then hydrogen sulfide can react with atmospheric oxygen in gaseous phase with precipitation of sulfur [66]:

$$
\begin{gathered}
2 \mathrm{H}_{2} \mathrm{~S}_{(\mathrm{g})}+\mathrm{O}_{2(\mathrm{~g})}=2 \mathrm{~S}_{(\mathrm{s})} \downarrow+2 \mathrm{H}_{2} \mathrm{O}_{(\mathrm{g})} \\
2 \mathrm{H}_{2} \mathrm{~S}_{(\mathrm{g})}+\mathrm{O}_{2(\mathrm{~g})}=2 \mathrm{SO}_{2(\mathrm{~g})}+2 \mathrm{H}_{2} \mathrm{O}_{(\mathrm{g})}, \\
2 \mathrm{H}_{2} \mathrm{~S}_{(\mathrm{g})}+\mathrm{SO}_{2(\mathrm{~g})}=3 \mathrm{~S} \downarrow+2 \mathrm{H}_{2} \mathrm{O}_{(\mathrm{g})} .
\end{gathered}
$$



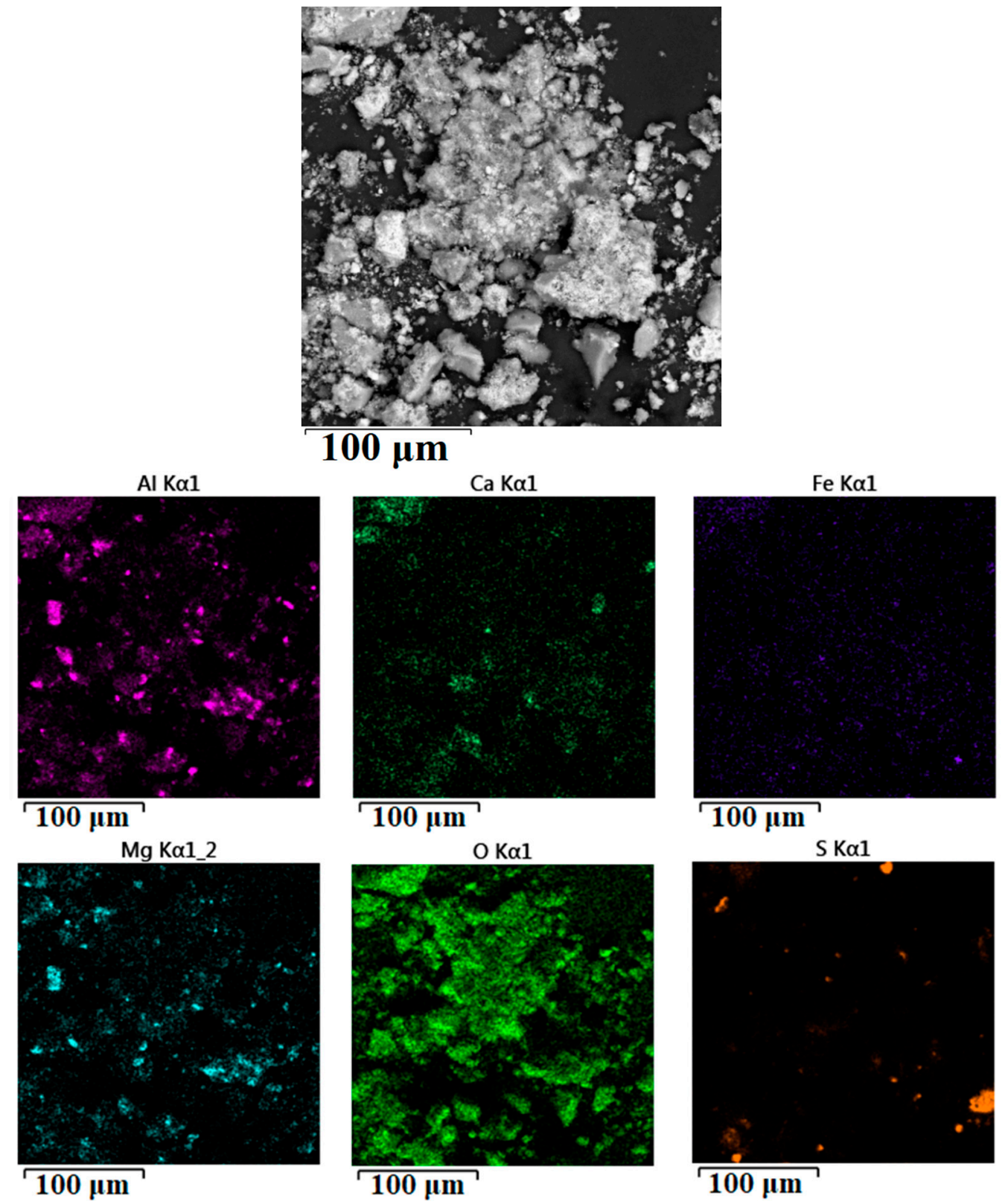
Si $K \alpha 1$
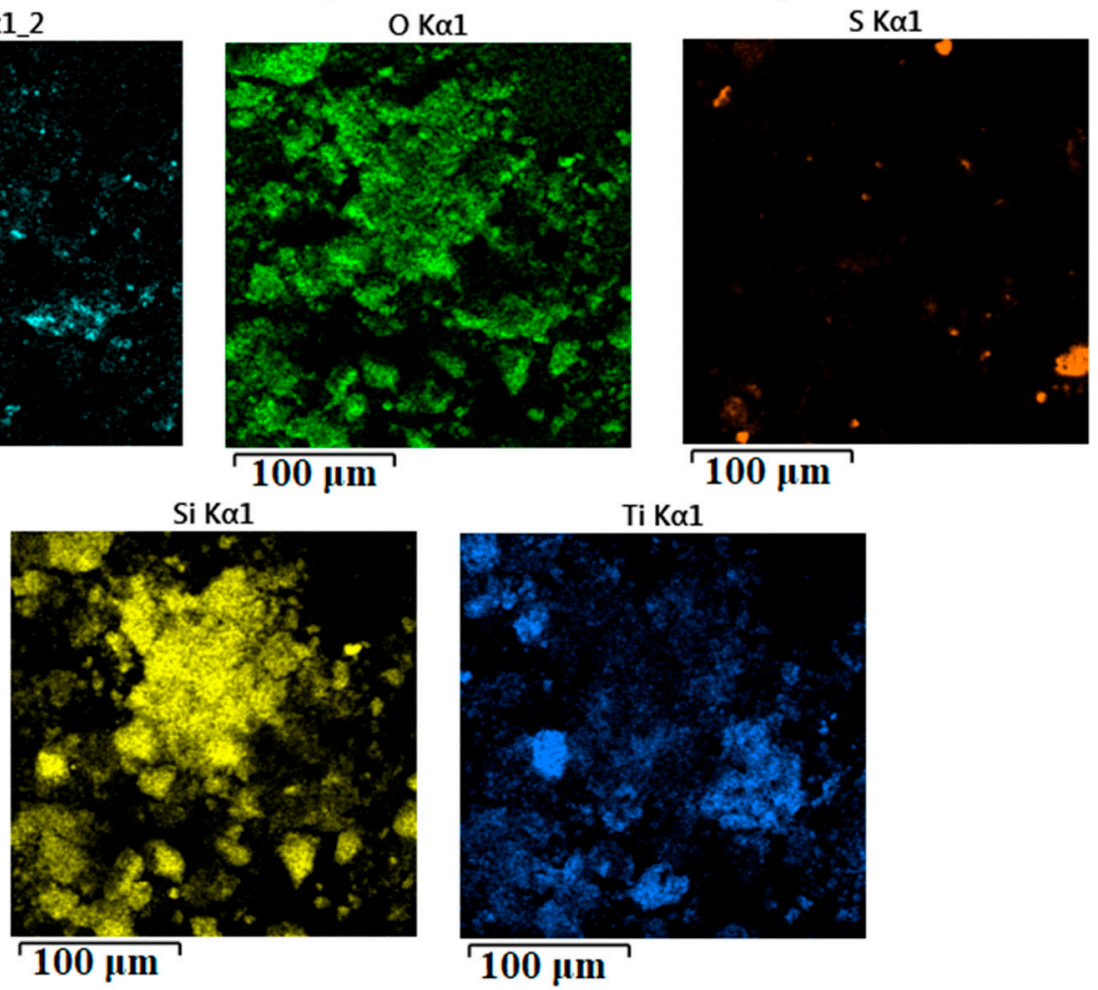

Figure 9. SEM images with the distribution of elements in the solid residue obtained by the leaching of the SSAT sample using $10 \% \mathrm{HCl}$ at $170{ }^{\circ} \mathrm{C}$ and $\mathrm{S}: \mathrm{L}$ ratio $=1: 11$ for $60 \mathrm{~min}$.

Moreover, sulfur forms quite likely by the interaction of hydrogen sulfide and ferric chloride [67]:

$$
\mathrm{H}_{2} \mathrm{~S}_{(\mathrm{g})}+2 \mathrm{FeCl}_{3(\mathrm{l})}=2 \mathrm{FeCl}_{2(\mathrm{l})}+\mathrm{S} \downarrow+2 \mathrm{HCl}_{(\mathrm{g})},
$$


Figure 10 shows the XRD patterns of the SSAT residues obtained at different leaching temperatures using both the $\mathrm{HCl}$ concentrations.

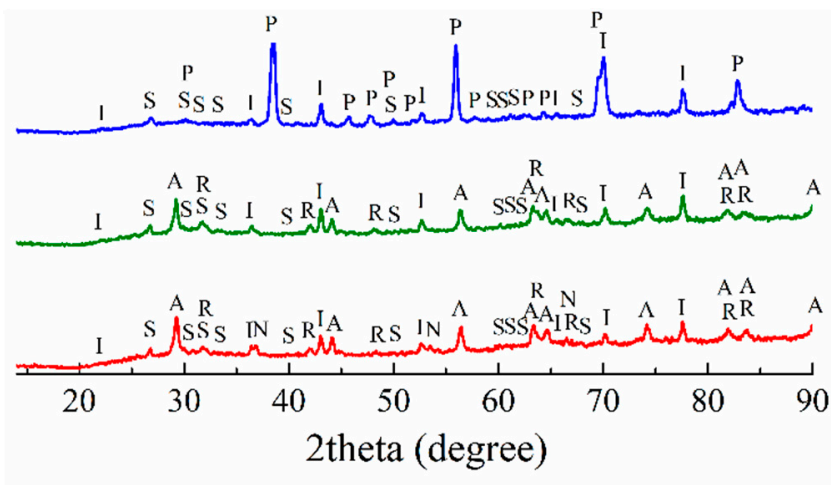

$-110^{\circ} \mathrm{C}-150^{\circ} \mathrm{C}-190^{\circ} \mathrm{C}$
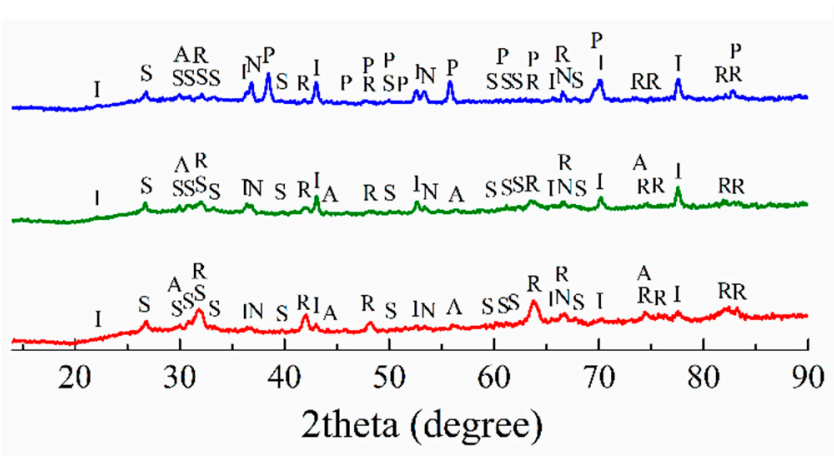

$190{ }^{\circ} \mathrm{C}$

(a)

(b)

Figure 10. The XRD patterns of the solid residues after the leaching of SSAT sample using $10 \%$ (a) and $20 \% \mathrm{HCl}(\mathbf{b})$, where $\mathrm{P}-\mathrm{CaTiO}_{3} ; \mathrm{A}-\mathrm{TiO}_{2}$ (anatase); $\mathrm{R}-\mathrm{TiO}_{2}$ (rutile); S-sulfur $\left(\alpha-\mathrm{S}_{8}\right) ; \mathrm{D}-5 \mathrm{Al}_{2} \mathrm{O}_{3} \cdot \mathrm{H}_{2} \mathrm{O} ; \mathrm{N}-\mathrm{NaCl} ; \mathrm{I}-\mathrm{MgAl}_{2} \mathrm{O}_{4}$.

The SSAT sample contains only one aluminum-containing phase, namely, $\mathrm{NaAlSiO}_{4}$, which is more soluble in acid solutions compared with $\mathrm{Ca}_{3} \mathrm{Al}_{2} \mathrm{Si}_{3} \mathrm{O}_{12}$ and $\mathrm{Ca}_{2} \mathrm{Al}_{2} \mathrm{SiO}_{7}$ phases, which is clearly seen from the XRD spectra. Nonetheless, aluminum passed into the solution incompletely even at high temperatures and acid concentrations due to the formation of $5 \mathrm{Al}_{2} \mathrm{O}_{3} \cdot \mathrm{H}_{2} \mathrm{O}$ and $\mathrm{MgAl}_{2} \mathrm{O}_{4}$ phases. Table 4 gives the elemental composition of the residues obtained by HPAL of the SSAT sample using the diluted and the concentrated acids. They mainly contain $\mathrm{SiO}_{2}$ and $\mathrm{TiO}_{2}$ that indicated to the same dissolution behavior of Ti and Si during leaching of the SSAT and WAT samples alike.

Table 4. Chemical composition of the solid residues obtained by the leaching of the SSAT sample at S:L ratio = 1:11 for $60 \mathrm{~min}(\mathrm{wt} . \%)$.

\begin{tabular}{ccccccc}
\hline HPAL Conditions & Al & Ca & Mg & Si & Ti & S \\
\hline $10 \% \mathrm{HCl}, 90^{\circ} \mathrm{C}$ & 4.86 & 7.65 & 1.31 & 18.1 & 8.66 & 7.22 \\
$10 \% \mathrm{HCl}, 210^{\circ} \mathrm{C}$ & 3.75 & 1.20 & 0.785 & 23.6 & 12.0 & 4.02 \\
$20 \% \mathrm{HCl}, 130^{\circ} \mathrm{C}$ & 5.98 & 2.30 & 1.51 & 21.7 & 3.41 & 8.50 \\
$20 \% \mathrm{HCl}, 210^{\circ} \mathrm{C}$ & 1.56 & 0.880 & 0.229 & 24.7 & 9.92 & 8.70 \\
\hline
\end{tabular}

As can be seen from Figures 3 and 5, the extraction degrees of Sc for the SSAT sample were lower compared to the WAT sample, probably owing to an increase of $\mathrm{pH}$ solution due to the dissolution of sodium, whose content in the SSAT sample is very high (Table 1). It is well-known that an increase of $\mathrm{pH}$ value of the solution led to a decrease of Sc extraction [47,48]. It has been previously reported [58] that a significant part of $Y$ and Sc can be associated with $\mathrm{NaAlSiO}_{4}$ in the tailings obtained after carbothermic roasting of red mud with the addition of sodium salts, but the present investigation has shown that there was no positive correlation between their dissolution. On the contrary, SEM-EDX analysis of the residue obtained by HPAL of the SSAT sample (Figure 11 and Table 5) indicates clearly that Sc along with $\mathrm{Zr}$ are predominantly associated with titanium. The detected presence of zirconium and scandium together and an increase of the Sc extraction degree with $\mathrm{Zr}$ dissolution degree rise in $20 \% \mathrm{HCl}$ (Figures 3 and 5) enable the assumption that a minor part of scandium is probably associated with zirconium minerals; this is consistent with the results of the authors [68], who noted that $10 \%$ of the total Sc is associated with $\mathrm{ZrSiO}_{4}$ in red mud. 


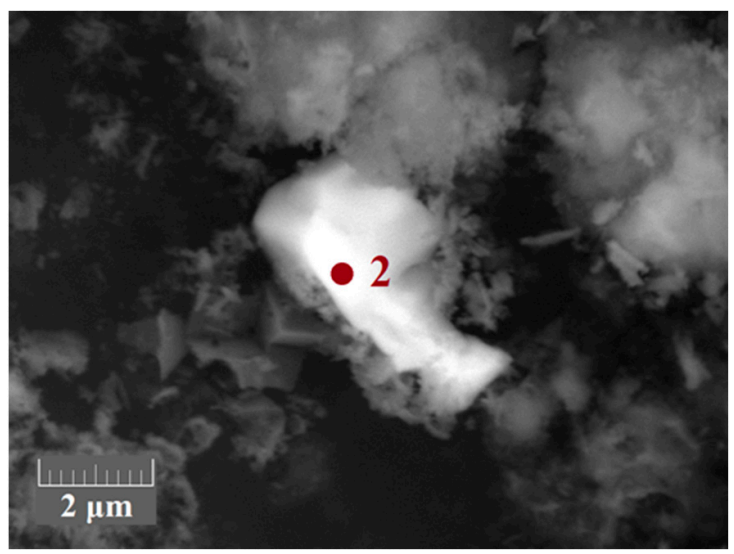

Figure 11. SEM image of an area in the solid residue obtained by the leaching of the SSAT sample using $10 \% \mathrm{HCl}$ at $170{ }^{\circ} \mathrm{C}$ and S:L ratio $=1: 11$ for $60 \mathrm{~min}$. The composition of the point 2 is given in Table 5 .

Table 5. Elemental composition (at.\%) of the sample point signed in Figure 11.

\begin{tabular}{ccccccccccc}
\hline Sign & $\mathbf{A l}$ & $\mathbf{S i}$ & $\mathbf{T i}$ & $\mathbf{C a}$ & $\mathbf{M g}$ & $\mathbf{Z r}$ & $\mathrm{Sc}$ & $\mathbf{S}$ & $\mathbf{C l}$ & $\mathbf{O}$ \\
\hline 2 & 2.60 & 5.20 & 20.7 & 5.40 & 0.80 & 3.20 & 1.40 & 0.600 & 0.300 & 59.7 \\
\hline
\end{tabular}

The optimal leaching conditions for the SSAT sample, which allows the extraction of $91 \% \mathrm{Al}, 75 \% \mathrm{Sc}, 63 \% \mathrm{Y}$, and more than $78 \%$ of other REEs, are $150{ }^{\circ} \mathrm{C}$ and $20 \% \mathrm{HCl}$ concentration. However, it should be appreciated that about $26 \% \mathrm{Ti}$ also passed into the solution under these conditions.

\subsection{HPAL Experiments with Variation of Leaching Time, S:L Ratio, and HCl Concentration}

The performed experiments have pointed out that the use of HPAL with hydrochloric acid for the WAT sample is more preferable compared to the SSAT sample due to the enabling of the selective separation of titanium and silicon from the other elements. To elucidate the dissolution behavior of the most important elements in the WAT sample, a set of the experiments at the optimal temperature with a variation of different leaching parameters was carried out. Figure 12 illustrates the influence of leaching duration on recovery degree of aluminum, titanium, iron, and scandium. An increase of leaching time led to insignificant growth of the extraction degree of Sc and Al for both the acid concentrations. Moreover, the decrease of leaching time led to an increase of Ti extraction degree, which negatively affects the process selectivity.

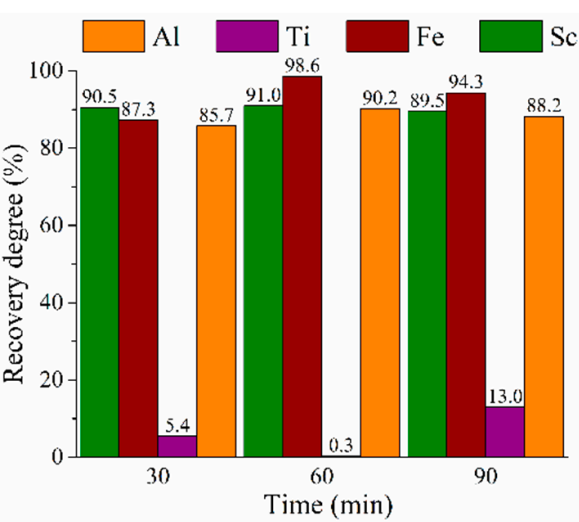

(a)

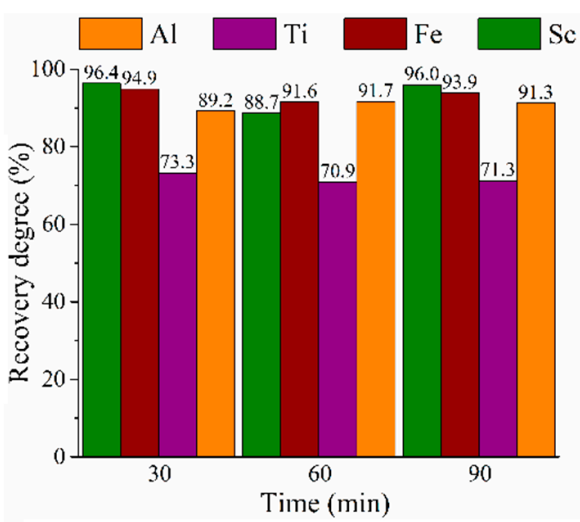

(b)

Figure 12. Effect of leaching time on the recovery degree of $\mathrm{Al}, \mathrm{Ti}, \mathrm{Fe}, \mathrm{Sc}$ at $150{ }^{\circ} \mathrm{C}$ and $\mathrm{S}: \mathrm{L}=1: 11$ using $10 \%$ (a) and $20 \%($ b) $\mathrm{HCl}$. 
Figure 13 demonstrates the influence of the S:L ratio and concentration of the acid on the recovery degree of aluminum, titanium, iron, and scandium. As can be seen, the dissolution degree of Ti drastically grows up with an increase of acid concentration and S:L ratio that is consistent with Equation (6). It has to be taken into account that an increase of S:L ratio led to a drop not only aluminum extraction degree, but also scandium extraction degree that is in accordance with previous studies $[69,70]$.

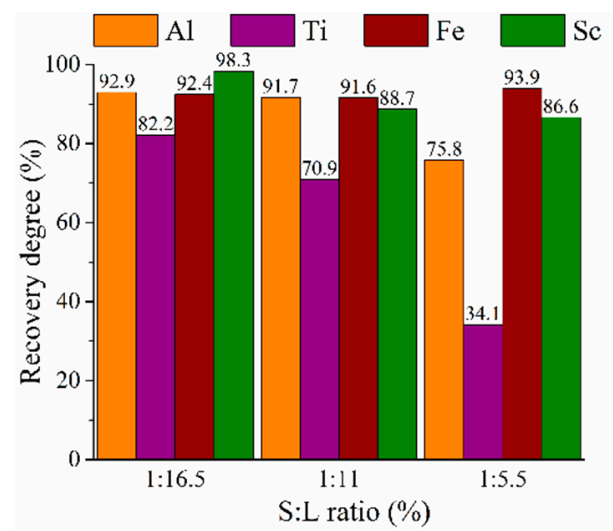

(a)

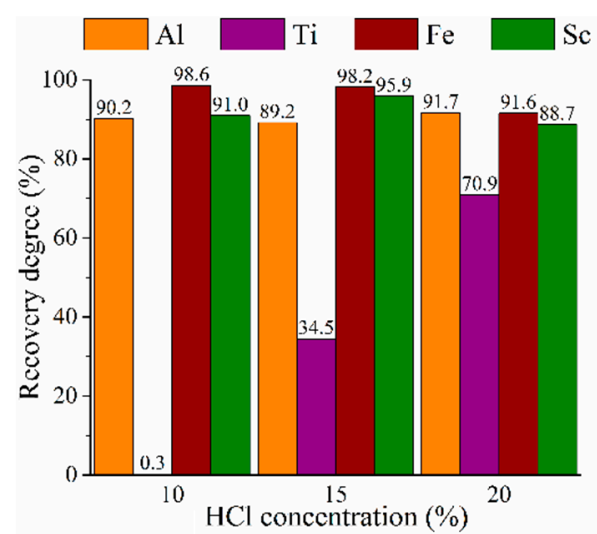

(b)

Figure 13. Effect of S: $\mathrm{L}$ ratio on the recovery degree of $\mathrm{Al}, \mathrm{Ti}, \mathrm{Fe}, \mathrm{Sc}$ at $150{ }^{\circ} \mathrm{C}$ and $20 \% \mathrm{HCl}$ (a) and effect of $\mathrm{HCl}$ concentration on recovery degree of $\mathrm{Al}, \mathrm{Ti}, \mathrm{Fe}, \mathrm{Sc}$ at $150{ }^{\circ} \mathrm{C}$ and $\mathrm{S}: \mathrm{L}=1: 11$ (b).

\section{Discussion}

The HPAL of the tailings using the diluted hydrochloric acid allows the selective separation of REEs and $\mathrm{Al}$ from $\mathrm{Ti}$ and $\mathrm{SiO}_{2}$ with high effectivity. The obtained residue can contain more than $20 \% \mathrm{TiO}_{2}$ and over $50 \% \mathrm{SiO}_{2}$ (Table 3) which indicates that it is a valuable raw material for $\mathrm{Ti}$ extraction. To extract $\mathrm{Ti}$, various leaching treatments have been suggested, such as using the mixture of hydrogen peroxide and sulfuric acid with a suppression of Si dissolution [71], as well as using alkaline solutions [72], phosphoric acid [47], etc. However, the most promising way for Ti extraction from the residue is the leaching by concentrated hydrochloric acid with its dissolution and subsequent precipitation of $\mathrm{TiO}_{2}$ [73]. The obtained amorphous $\mathrm{SiO}_{2}$ can be used for the production of white carbon black [74].

REEs can be relatively simply recovered from the leached solutions by well-known methods, e.g., solvent extraction, ion-exchange sorption, selective precipitation, etc. [75]. The remaining aluminum chloride solution can be used as a coagulant for water treatment $[62,76]$ or as a raw material for the production of metallurgical alumina [77]. Thus, a two-step hydrochloric acid leaching process can be implemented.

As reflected by Figure 13, the application of $20 \% \mathrm{HCl}$ with S:L ratio of 1:16.5 led to a considerable rise of $\mathrm{Al}, \mathrm{Ti}, \mathrm{Sc}$ extraction degree that enables the consideration of the simultaneous dissolution of these elements with a following stepwise extraction of REEs and titanium from the leached solution. Moreover, after the REE extraction, AlTi-containing solution can be regarded as a complex coagulant, which has an increased efficiency for waste water treatment compared with the Ti-free solutions $[78,79]$. However, it should be noted that the use of an excess of acid and liquid-to-solid ratio during HPAL deteriorates the cost efficiency of the process, so a feasibility study is necessary.

The application of the HPAL method using $\mathrm{HCl}$ led to a similar $\mathrm{Al}$ recovery for the WAT and SSAT samples, but the treatment of the SSAT resulted in a rather lower Sc recovery and a slightly higher acid consumption. Furthermore, the residue obtained by the leaching of the SSAT sample can contain a substantial percentage of elemental sulfur and sodium chloride, so additional stages for their removal is necessary. The process of elemental sulfur precipitation is given in Section 3.2.2; sodium chloride was likely precipitated during the filtration of the mother liquors. To remove $\mathrm{NaCl}$, washing by water can be applied, 
and to extract elemental sulfur, distillation [80] or flotation [81] can be used. Despite the mentioned disadvantages of the SSAT leaching, the total cost of red mud processing using sodium sulfate may be lower owing to the reduced roasting temperature and improved grindability of the roasted sample. Moreover, the cost of both flowsheets can be additionally reduced by the replacement of a carbonaceous reductant with blast furnace sludge [82]. In any case, a comparative economic assessment of the treatment of the WAT and SSAT samples is required.

Figure 14 shows two principal flowsheets of red mud processing developed as a result of the study.

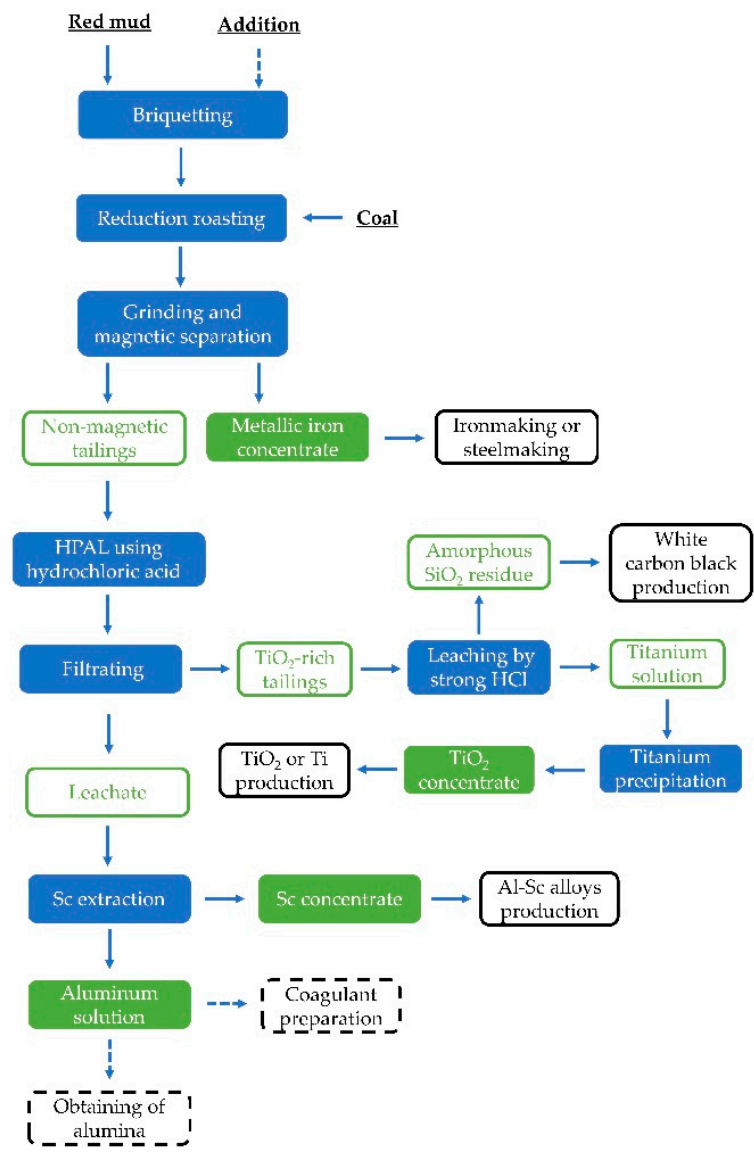

(a)

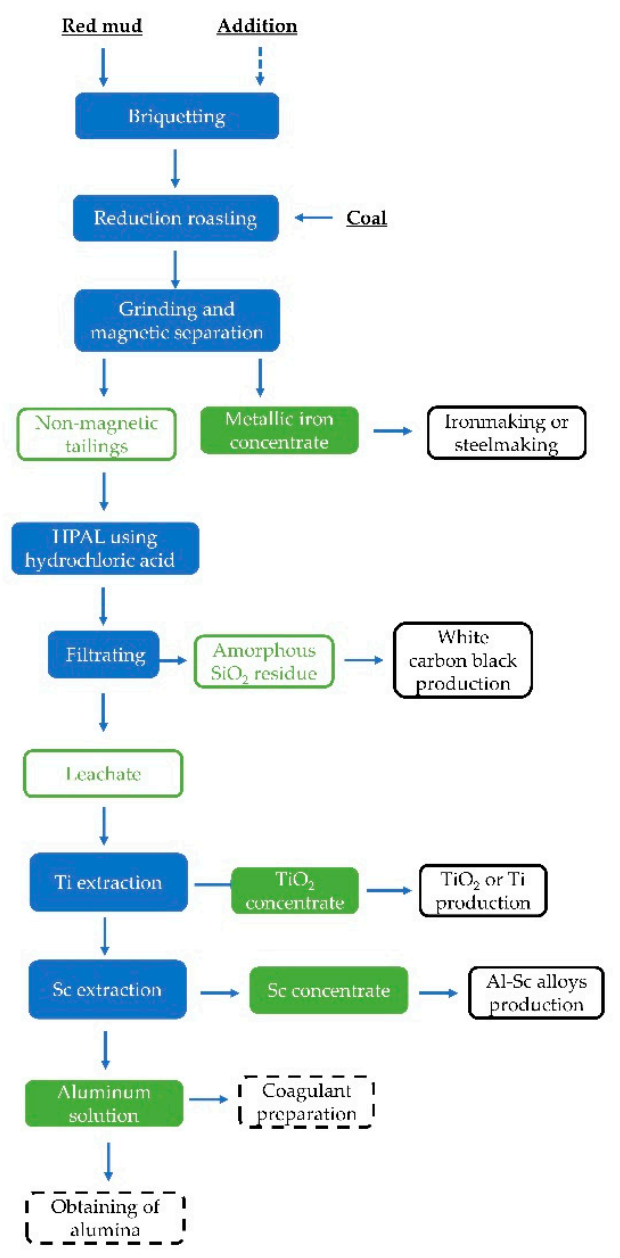

(b)

Figure 14. The flowsheets of red mud processing using two (a) and one (b) leaching stages.

The suggested flowsheets aimed at a comprehensive utilization of red mud with the extraction of all valuable components. The recovery of iron by reduction roasting at the first stage at 1150 to $1300{ }^{\circ} \mathrm{C}$ allows the reduction of energy costs compared with a reduction smelting with the application of a low-grade coal or carbon-containing waste as a reducing agent.

As mentioned above, hydrochloric acid leaching is an effective method for the alumina recovery, and it was used on a pilot scale to extract $\mathrm{Al}_{2} \mathrm{O}_{3}$ from coal fly ash in China [83]. To obtain polyaluminum chloride, 30 to $32 \% \mathrm{HCl}$ is commonly used to dissolve aluminum hydroxide. The process occurs using high-pressure leaching in reactors at 150 to $180{ }^{\circ} \mathrm{C}$ depending on the charge material. The use of 3-6 $\mathrm{M} \mathrm{HCl}$ is due to the possibility of acid regeneration during the thermal hydrolysis of aluminum chloride hexahydrate to obtain 
alumina. The hydrochloric acid flowsheet involves obtaining alumina by the precipitation of salt from an acidic aluminum chloride solution followed by calcination of the salt to form aluminum oxide. Hydrochloric acid regenerates simply $-\mathrm{HCl}$ vapor bubbles through the water, so up to $6 \mathrm{M} \mathrm{HCl}$ can be obtained. Hence, the proposed flowsheets can be characterized by a low environmental impact.

It also should be noted that there is a high flexibility of the suggested flowsheets. The process can be organized to obtain high-demand products at the moment. For example, at high prices for alumina, it can be extracted from the solution; otherwise, the coagulants can be obtained. In the same way, based on market conditions, titanium can be passed into solution to obtain complex coagulants, or it can be extracted into a particular product. An engineering and economic evaluation of the flowsheets is possible after obtaining and characterizing the final products, namely, the REE and titanium concentrates, white carbon black, the coagulants, and alumina. However, the above-mentioned advantages and a possibility of obtaining various high-demand products indicate the economic feasibility of the proposed methods.

\section{Conclusions}

The application of HPAL using hydrochloric acid for the extraction of $\mathrm{Al}$ and REEs from non-magnetic tailings obtained from red mud after iron removal has shown a high effectivity. The leaching of valuable elements from the WAT sample is probably more preferable than from the SSAT sample.

For the WAT sample, the optimal leaching conditions, which are leaching temperature of $150{ }^{\circ} \mathrm{C}$, acid concentration of $10 \%$, solid-to-liquid ratio of $1: 11$, and duration of $60 \mathrm{~min}$, led to passing into solution of $90 \% \mathrm{Al}, 91 \% \mathrm{Sc}$ and above $80 \%$ of other REEs, as well as maintaining $\mathrm{TiO}_{2}$ and $\mathrm{SiO}_{2}$ in the residue. To dissolve titanium along with $\mathrm{Al}$ and REEs, the temperature of $150{ }^{\circ} \mathrm{C}$, acid concentration of $20 \%$, solid-to-liquid ratio of $1: 16.5$, and duration of $60 \mathrm{~min}$ can be applied to allow the extraction of $93 \% \mathrm{Al}, 82 \% \mathrm{Ti}, 98 \% \mathrm{Sc}$.

For the SSAT sample, $91 \% \mathrm{Al}, 75 \% \mathrm{Sc}$, above $60 \%$ of other REEs, and $26 \%$ Ti were dissolved under the optimal conditions, which were a leaching temperature of $150{ }^{\circ} \mathrm{C}$, acid concentration of $20 \%$, solid-to-liquid ratio of 1:11, and duration of $60 \mathrm{~min}$.

Based on HPAL using hydrochloric acid, two flowsheets were proposed for the treatment of both kinds of non-magnetic tailings.

Author Contributions: Conceptualization, D.Z. and P.G.; Methodology, D.Z., P.G., and A.V.; Investigation, E.Z., D.G., and A.V.; Resources, V.D.; Writing-original draft preparation, D.Z. and P.G.; Writing-review and editing, A.V.; Visualization, P.G. and D.G.; Supervision, V.D. and A.P.; Project administration, V.D. and A.P.; Funding acquisition, A.P. All authors have read and agreed to the published version of the manuscript.

Funding: The present study was funded by RFBR according to Research Project No. 18-29-24186. Access to the electronic database of scientific publications was provided within Russian state assignment No. 075-00328-21-00.

Data Availability Statement: Data sharing not applicable.

Acknowledgments: The authors would like to appreciate the Chemical Analytical Laboratory of the JSC “Design \& Survey and Research \& Development Institute of Industrial Technology" for chemical analysis and to express profound appreciation to Dmitry Valeev for valuable remarks and discussion of the manuscript.

Conflicts of Interest: The authors declare no conflict of interest.

\section{References}

1. Zeng, H.; Lyu, F.; Sun, W.; Zhang, H.; Wang, L.; Wang, Y. Progress on the industrial applications of red mud with a focus on China. Minerals 2020, 10, 773. [CrossRef]

2. Wang, L.; Sun, N.; Tang, H.; Sun, W. A Review on Comprehensive Utilization of Red Mud. Minerals 2019, 9, 362. [CrossRef]

3. Service, R.F. Red Mud Is Piling up. Can Scientists Figure out What to Do with It? Available online: https://www.sciencemag. org/news/2020/08/red-mud-piling-can-scientists-figure-out-what-do-it (accessed on 25 November 2020). 
4. Archambo, M.; Kawatra, S.K. Red Mud: Fundamentals and New Avenues for Utilization. Miner. Process. Extr. Metall. Rev. 2020, 1-24. [CrossRef]

5. Pietrelli, L.; Ippolito, N.M.; Ferro, S.; Dovi, V.G.; Vocciante, M. Removal of Mn and As from drinking water by red mud and pyrolusite. J. Environ. Manag. 2019, 237, 526-533. [CrossRef]

6. Wang, S.; Ang, H.M.; Tadé, M.O. Novel applications of red mud as coagulant, adsorbent and catalyst for environmentally benign processes. Chemosphere 2008, 72, 1621-1635. [CrossRef]

7. Joseph, C.G.; Taufiq-Yap, Y.H.; Krishnan, V.; Li Puma, G. Application of modified red mud in environmentally-benign applications: A review paper. Environ. Eng. Res. 2020, 25, 795-806. [CrossRef]

8. Khairul, M.A.; Zanganeh, J.; Moghtaderi, B. The composition, recycling and utilisation of Bayer red mud. Resour. Conserv. Recycl. 2019, 141, 483-498. [CrossRef]

9. Liu, Y.; Naidu, R. Hidden values in bauxite residue (red mud): Recovery of metals. Waste Manag. 2014, 34, 2662-2673. [CrossRef]

10. Akcil, A.; Akhmadiyeva, N.; Abdulvaliyev, R.; Meshram, A.; Meshram, P. Overview On Extraction and Separation of Rare Earth Elements from Red Mud: Focus on Scandium. Miner. Process. Extr. Metall. Rev. 2018, 39, 145-151. [CrossRef]

11. Kumar, S.; Kumar, R.; Bandopadhyay, A. Innovative methodologies for the utilisation of wastes from metallurgical and allied industries. Resour. Conserv. Recycl. 2006, 48, 301-314. [CrossRef]

12. Roy, S.K.; Nayak, D.; Rath, S.S. A review on the enrichment of iron values of low-grade Iron ore resources using reduction roasting-magnetic separation. Powder Technol. 2020, 367, 796-808. [CrossRef]

13. Liu, Z.; Li, H. Metallurgical process for valuable elements recovery from red mud-A review. Hydrometallurgy 2015, 155, 29-43. [CrossRef]

14. Avdibegović, D.; Regadío, M.; Binnemans, K. Efficient separation of rare earths recovered by a supported ionic liquid from bauxite residue leachate. RSC Adv. 2018, 8, 11886-11893. [CrossRef]

15. Meng, F.; Li, X.; Wang, P.; Yang, F.; Liang, D.; Gao, F.; He, C.; Wei, Y. Recovery of Scandium from Bauxite Residue by Selective Sulfation Roasting with Concentrated Sulfuric Acid and Leaching. JOM 2020, 72, 816-822. [CrossRef]

16. Narayanan, R.P.; Kazantzis, N.K.; Emmert, M.H. Selective Process Steps for the Recovery of Scandium from Jamaican Bauxite Residue (Red Mud). ACS Sustain. Chem. Eng. 2018, 6, 1478-1488. [CrossRef]

17. Bayca, S.U.; Kisik, H. Optimization of leaching parameters of aluminum hydroxide extraction from bauxite waste using the Taguchi method. Environ. Prog. Sustain. Energy 2018, 37, 196-202. [CrossRef]

18. Vaylert, A.V.; Pyagay, I.N.; Kozhevnikov, V.L.; Pasechnik, L.A.; Yatsenko, S.P. Autoclave hydrometallurgical processing of alumina production red mud. Tsvetnye Met. 2014, 3, 27-31.

19. Shoppert, A.A.; Loginova, I.V. Red Mud as an Additional Source of Titanium Raw Materials. KnE Mater. Sci. 2017, 2, 150-157. [CrossRef]

20. Agrawal, S.; Dhawan, N. Investigation of mechanical and thermal activation on metal extraction from red mud. Sustain. Mater. Technol. 2021, 27, e00246. [CrossRef]

21. Reid, S.; Tam, J.; Yang, M.; Azimi, G. Technospheric Mining of Rare Earth Elements from Bauxite Residue (Red Mud): Process Optimization, Kinetic Investigation, and Microwave Pretreatment. Sci. Rep. 2017, 7, 1-9. [CrossRef]

22. Ochsenkuehn-Petropoulou, M.; Tsakanika, L.-A.; Lymperopoulou, T.; Ochsenkuehn, K.-M.; Hatzilyberis, K.; Georgiou, P.; Stergiopoulos, C.; Serifi, O.; Tsopelas, F. Efficiency of Sulfuric Acid on Selective Scandium Leachability from Bauxite Residue. Metals 2018, 8, 915. [CrossRef]

23. Xie, W.; Zhang, N.; Li, J.; Zhou, F.; Ma, X.; Gu, G.; Zhang, W. Optimization of condition for extraction of aluminum and iron from red mud by hydrochloric acid leaching. Chin. J. Environ. Eng. 2017, 11, 5677-5682. [CrossRef]

24. Alkan, G.; Schier, C.; Gronen, L.; Stopic, S.; Friedrich, B. A Mineralogical Assessment on Residues after Acidic Leaching of Bauxite Residue (Red Mud) for Titanium Recovery. Metals 2017, 7, 458. [CrossRef]

25. Zhu, X.; Niu, Z.; Li, W.; Zhao, H.; Tang, Q. A novel process for recovery of aluminum, iron, vanadium, scandium, titanium and silicon from red mud. J. Environ. Chem. Eng. 2019, 8, 103528. [CrossRef]

26. Gu, H.; Li, W.; Li, Z.; Guo, T.; Wen, H.; Wang, N. Leaching Behavior of Lithium from Bauxite Residue Using Acetic Acid. Min. Metall. Explor. 2020, 37, 443-451. [CrossRef]

27. Atalay Kalsen, T.S.; Karadağ, H.B.; Eker, Y.R.; Kerti, I. Chemical Composition Simplification of the Seydişehir (Konya, Turkey) Alumina Plant Waste. J. Sustain. Metall. 2019, 5, 482-496. [CrossRef]

28. Davris, P.; Balomenos, E.; Panias, D.; Paspaliaris, I. Selective leaching of rare earth elements from bauxite residue (red mud), using a functionalized hydrophobic ionic liquid. Hydrometallurgy 2016, 164, 125-135. [CrossRef]

29. Onghena, B.; Binnemans, K. Recovery of Scandium(III) from aqueous solutions by solvent extraction with the functionalized ionic liquid betainium bis(trifluoromethylsulfonyl)imide. Ind. Eng. Chem. Res. 2015, 54, 1887-1898. [CrossRef]

30. Rivera, R.M.; Xakalashe, B.; Ounoughene, G.; Binnemans, K.; Friedrich, B.; Van Gerven, T. Selective rare earth element extraction using high-pressure acid leaching of slags arising from the smelting of bauxite residue. Hydrometallurgy 2019, 184, 162-174. [CrossRef]

31. Zinoveev, D.V.; Grudinskii, P.I.; Dyubanov, V.G.; Kovalenko, L.V.; Leont'ev, L.I. Global recycling experience of red mud-A review. Part I: Pyrometallurgical methods. Izv. Ferr. Metall. 2018, 61, 843-858. [CrossRef]

32. Alkan, G.; Xakalashe, B.; Yagmurlu, B.; Kaußen, F.; Friedrich, B. Conditioning of red mud for subsequent titanium and scandium recovery-A conceptual design study. World Metall. Erzmetall 2017, 70, 5-12. 
33. Balomnenos, E.; Kastritis, D.; Panias, D.; Paspaliaris, I.; Boufounos, D. The Enexal Bauxite Residue Treatment Process: Industrial Scale Pilot Plant Results. In Light Metals 2014; Grandfield, J., Ed.; Springer: Cham, Switzerland, 2014; pp. 143-147. [CrossRef]

34. Mombelli, D.; Mapelli, C.; Barella, S.; Gruttadauria, A.; Ragona, M.; Pisu, M.; Viola, A. Characterization of cast iron and slag produced by red muds reduction via Arc Transferred Plasma (ATP) reactor under different smelting conditions. J. Environ. Chem. Eng. 2020, 8, 104293. [CrossRef]

35. Ning, G.; Zhang, B.; Liu, C.; Li, S.; Ye, Y.; Jiang, M. Large-Scale Consumption and Zero-Waste Recycling Method of Red Mud in Steel Making Process. Minerals 2018, 8, 102. [CrossRef]

36. Borra, C.R.; Blanpain, B.; Pontikes, Y.; Binnemans, K.; Van Gerven, T. Recovery of Rare Earths and Major Metals from Bauxite Residue (Red Mud) by Alkali Roasting, Smelting, and Leaching. J. Sustain. Metall. 2017, 3, 393-404. [CrossRef]

37. Chun, T.J.; Zhu, D.Q.; Pan, J.; He, Z. Preparation of metallic iron powder from red mud by sodium salt roasting and magnetic separation. Can. Metall. Q. 2014, 53, 183-189. [CrossRef]

38. Ding, W.; Xiao, J.-H.; Peng, Y.; Shen, S.-Y.; Chen, T. Iron Extraction from Red Mud using Roasting with Sodium Salt. Miner. Process. Extr. Metall. Rev. 2019, 1-9. [CrossRef]

39. Zinoveev, D.; Grudinsky, P.; Zakunov, A.; Semenov, A.; Panova, M.; Valeev, D.; Kondratiev, A.; Dyubanov, V.; Petelin, A. Influence of $\mathrm{Na}_{2} \mathrm{CO}_{3}$ and $\mathrm{K}_{2} \mathrm{CO}_{3}$ addition on iron grain growth during carbothermic reduction of red mud. Metals 2019, 9, 1313. [CrossRef]

40. Chun, T.; Li, D.; Di, Z.; Long, H.; Tang, L.; Li, F.; Li, Y. Recovery of iron from red mud by high temperature reduction of carbon bearing briquettes. J. South. Afr. Inst. Min. Metall. 2017, 117, 361-364. [CrossRef]

41. Zhu, D.Q.; Chun, T.J.; Pan, J.; He, Z. Recovery of Iron From High-Iron Red Mud by Reduction Roasting with Adding Sodium Salt. J. Iron Steel Res. Int. 2012, 19, 1-5. [CrossRef]

42. Ding, W.; Peng, Y.; Wu, Q.; Shen, S.; Xiao, J.; Liang, G.; Huang, W. Increase of iron concentration and reduction of impurities in red mud from the Wenshan area of Yunnan Province by segregation roasting-low intensity magnetic separation. J. Mines Met. Fuels 2019, 67, 377-384.

43. Gao, F.; Zhang, J.; Deng, X.; Wang, K.; He, C.; Li, X.; Wei, Y. Comprehensive Recovery of Iron and Aluminum from Ordinary Bayer Red Mud by Reductive Sintering-Magnetic Separation-Digesting Process. JOM 2019, 71, 2936-2943. [CrossRef]

44. Li, G.; Luo, J.; Jiang, T.; Li, Z.; Peng, Z.; Zhang, Y. Digestion of alumina from non-magnetic material obtained from magnetic separation of reduced iron-rich diasporic bauxite with sodium salts. Metals 2016, 6, 294. [CrossRef]

45. Li, G.; Liu, M.; Rao, M.; Jiang, T.; Zhuang, J.; Zhang, Y. Stepwise extraction of valuable components from red mud based on reductive roasting with sodium salts. J. Hazard. Mater. 2014, 280, 774-780. [CrossRef]

46. Rivera, R.M.; Ulenaers, B.; Ounoughene, G.; Binnemans, K. Behaviour of Silica during Metal Recovery from Bauxite Residue by Acidic Leaching. In Proceedings of the 35th International ICSOBA Conference, Hamburg, Germany, 2-5 October 2017; Académie Croate Des Sciences Et Des Arts: Hamburg, Germany, 2017; pp. 547-556.

47. Deng, B.; Li, G.; Luo, J.; Ye, Q.; Liu, M.; Peng, Z.; Jiang, T. Enrichment of $\mathrm{Sc}_{2} \mathrm{O}_{3}$ and $\mathrm{TiO}_{2}$ from bauxite ore residues. J. Hazard. Mater. 2017, 331, 71-80. [CrossRef]

48. Borra, C.R.; Blanpain, B.; Pontikes, Y.; Binnemans, K.; Van Gerven, T. Smelting of Bauxite Residue (Red Mud) in View of Iron and Selective Rare Earths Recovery. J. Sustain. Metall. 2016, 2, 28-37. [CrossRef]

49. Valeev, D.; Kunilova, I.; Alpatov, A.; Mikhailova, A.; Goldberg, M.; Kondratiev, A. Complex utilisation of ekibastuz brown coal fly ash: Iron \& carbon separation and aluminum extraction. J. Clean. Prod. 2019, 218, 192-201. [CrossRef]

50. Valeev, D.V.; Lainer, Y.A.; Pak, V.I. Autoclave leaching of boehmite-kaolinite bauxites by hydrochloric acid. Inorg. Mater. Appl. Res. 2016, 7, 272-277. [CrossRef]

51. Valeev, D.V.; Lainer, Y.A.; Mikhailova, A.B.; Dorofievich, I.V.; Zheleznyi, M.V.; Gol'dberg, M.A.; Kutsev, S.V. Reaction of Bauxite with Hydrochloric Acid Under Autoclave Conditions. Metallurgist 2016, 60, 204-211. [CrossRef]

52. Li, S.; Qin, S.; Kang, L.; Liu, J.; Wang, J.; Li, Y. An Efficient Approach for Lithium and Aluminum Recovery from Coal Fly Ash by Pre-Desilication and Intensified Acid Leaching Processes. Metals 2017, 7, 272. [CrossRef]

53. Grudinsky, P.; Zinoveev, D.; Pankratov, D.; Semenov, A.; Panova, M.; Kondratiev, A.; Zakunov, A.; Dyubanov, V.; Petelin, A. Influence of Sodium Sulfate Addition on Iron Grain Growth during Carbothermic Roasting of Red Mud Samples with Different Basicity. Metals 2020, 10, 1571. [CrossRef]

54. Match! Version 3.11; Software for Identification of Powder Diffraction Patterns; Crystal Impact: Bonn, Germany, 2021.

55. Falayi, T.; Ntuli, F.; Ndubisi, F. Kinetic and thermodynamic parameters of silica leaching from Camden power station fly ash. In Proceedings of the 4th NAUN International Conference on Energy Systems, Environment, Entrepreneurship and Innovation (ICESEEI'15), Dubai, United Arab Emirates, 22-24 February 2015; WSEAS: Dubai, United Arab Emirates, 2017 ; pp. $241-248$.

56. Han, J.; Zhang, J.; Feng, W.; Chen, X.; Zhang, L.; Tu, G. A clean process to prepare high-quality acid-soluble titanium slag from titanium middling ore. Minerals 2019, 9, 460. [CrossRef]

57. Liu, Y.; Shao, D.; Wang, W.; Yi, L.; Chen, D.; Zhao, H.; Wu, J.; Qi, T.; Cao, C. Preparation of rutile $\mathrm{TiO}_{2}$ by hydrolysis of TiOCl 2 solution: Experiment and theory. RSC Adv. 2016, 6, 59541-59549. [CrossRef]

58. Deng, B.; Li, G.; Luo, J.; Ye, Q.; Liu, M.; Rao, M.; Jiang, T.; Bauman, L.; Zhao, B. Selectively leaching the iron-removed bauxite residues with phosphoric acid for enrichment of rare earth elements. Sep. Purif. Technol. 2019, 227, 115714. [CrossRef]

59. Wajima, T. Effects of step-wise acid leaching with $\mathrm{HCl}$ on synthesis of zeolitic materials from paper sludge ash. Minerals 2020, 10, 402. [CrossRef] 
60. Rivera, R.M.; Ulenaers, B.; Ounoughene, G.; Binnemans, K.; Van Gerven, T. Extraction of rare earths from bauxite residue (red mud) by dry digestion followed by water leaching. Miner. Eng. 2018, 119, 82-92. [CrossRef]

61. Yu, W.; Wen, X.; Chen, J.; Tang, Q.; Dong, W.; Zhong, J. Effect of Sodium Borate on the Preparation of TiN from Titanomagnetite Concentrates by Carbothermic Reduction-Magnetic Separation and Acid Leaching Process. Minerals 2019, 9, 675. [CrossRef]

62. Zhao, Y.; Zheng, Y.; He, H.; Sun, Z.; Li, A. Effective aluminum extraction using pressure leaching of bauxite reaction residue from coagulant industry and leaching kinetics study. J. Environ. Chem. Eng. 2020, in press. [CrossRef]

63. Digne, M.; Sautet, P.; Raybaud, P.; Toulhoat, H.; Artacho, E. Structure and stability of aluminum hydroxides: A theoretical study. J. Phys. Chem. B 2002, 106, 5155-5162. [CrossRef]

64. Shrivastava, O.P.; Kumar, N.; Sharma, I.B. Solid state synthesis and structural refinement of polycrystalline $\mathrm{La}_{\mathrm{x}} \mathrm{Ca}_{1-\mathrm{x}} \mathrm{TiO}_{3} \mathrm{ceramic}$ powder. Bull. Mater. Sci. 2004, 27, 121-126. [CrossRef]

65. Anawati, J.; Azimi, G. Recovery of scandium from Canadian bauxite residue utilizing acid baking followed by water leaching. Waste Manag. 2019, 95, 549-559. [CrossRef] [PubMed]

66. Steijns, M.; Derks, F.; Verloop, A.; Mars, P. The mechanism of the catalytic oxidation of hydrogen sulfide. II. Kinetics and mechanism of hydrogen sulfide oxidation catalyzed by sulfur. J. Catal. 1976, 42, 87-95. [CrossRef]

67. Kshumaneva, E.S.; Kasikov, A.G.; Neradovskii, Y.N. Behavior of sulfides of nonferrous metals in hydrochloric-acid leaching of residues formed in synthesis of carbonyl nickel. Russ. J. Appl. Chem. 2005, 78, 178-183. [CrossRef]

68. Vind, J.; Malfliet, A.; Bonomi, C.; Paiste, P.; Sajó, I.E.; Blanpain, B.; Tkaczyk, A.H.; Vassiliadou, V.; Panias, D. Modes of occurrences of scandium in Greek bauxite and bauxite residue. Miner. Eng. 2018, 123, 35-48. [CrossRef]

69. Huang, F.; Liao, Y.; Zhou, J.; Wang, Y.; Li, H. Selective recovery of valuable metals from nickel converter slag at elevated temperature with sulfuric acid solution. Sep. Purif. Technol. 2015, 156, 572-581. [CrossRef]

70. Borra, C.R.; Pontikes, Y.; Binnemans, K.; Van Gerven, T. Leaching of rare earths from bauxite residue (red mud). Miner. Eng. 2015, 76, 20-27. [CrossRef]

71. Alkan, G.; Yagmurlu, B.; Cakmakoglu, S.; Hertel, T.; Kaya, Ş.; Gronen, L.; Stopic, S.; Friedrich, B. Novel Approach for Enhanced Scandium and Titanium Leaching Efficiency from Bauxite Residue with Suppressed Silica Gel Formation. Sci. Rep. 2018, 8, 5676. [CrossRef]

72. Zablotskaya, Y.V.; Sadykhov, G.B.; Gocharenko, T.V. Autoclave leaching kinetics of a leucoxene concentrate with alkaline solutions. Russ. Metall. 2015, 2015, 3-7. [CrossRef]

73. Wang, Z.; Liu, S.; Cao, X.; Wu, S.; Liu, C.; Li, G.; Jiang, W.; Wang, H.; Wang, N.; Ding, W. Preparation and characterization of TiO 2 nanoparticles by two different precipitation methods. Ceram. Int. 2020, 46, 15333-15341. [CrossRef]

74. Yuan, W.; Yao, Z.; Zhang, Q.; Li, J. Characterization of residue from leached cathode ray tube funnel glass: Reutilization as white carbon black. J. Mater. Cycles Waste Manag. 2014, 16, 629-634. [CrossRef]

75. Borra, C.R.; Blanpain, B.; Pontikes, Y.; Binnemans, K.; Van Gerven, T. Recovery of Rare Earths and Other Valuable Metals From Bauxite Residue (Red Mud): A Review. J. Sustain. Metall. 2016, 2, 365-386. [CrossRef]

76. Valeev, D.; Kunilova, I.; Shoppert, A.; Salazar-Concha, C.; Kondratiev, A. High-pressure HCl leaching of coal ash to extract Al into a chloride solution with further use as a coagulant for water treatment. J. Clean. Prod. 2020, 276, 123206. [CrossRef]

77. Valeev, D.; Shoppert, A.; Mikhailova, A.; Kondratiev, A. Acid and Acid-Alkali Treatment Methods of Al-Chloride Solution Obtained by the Leaching of Coal Fly Ash to Produce Sandy Grade Alumina. Metals 2020, 10, 585. [CrossRef]

78. Azopkov, S.V.; Kuzin, E.N.; Kruchinina, N.E. Study of the Efficiency of Combined Titanium Coagulants in the Treatment of Formation Waters. Russ. J. Gen. Chem. 2020, 90, 1811-1816. [CrossRef]

79. Kuzin, E.N.; Kruchinina, N.E. Purification of circulating and waste water in metallurgical industry using complex coagulants. CIS Iron Steel Rev. 2019, 18, 72-75. [CrossRef]

80. Li, H.; Wu, X.; Wang, M.; Wang, J.; Wu, S.; Yao, X.; Li, L. Separation of elemental sulfur from zinc concentrate direct leaching residue by vacuum distillation. Sep. Purif. Technol. 2014, 138, 41-46. [CrossRef]

81. Liu, G.; Jiang, K.; Zhang, B.; Dong, Z.; Zhang, F.; Wang, F.; Jiang, T.; Xu, B. Selective Flotation of Elemental Sulfur from Pressure Acid Leaching Residue of Zinc Sulfide. Minerals 2021, 11, 89. [CrossRef]

82. Mombelli, D.; Barella, S.; Gruttadauria, A.; Mapelli, C. Iron recovery from Bauxite Tailings Red Mud by thermal reduction with blast furnace sludge. Appl. Sci. 2019, 9, 4902. [CrossRef]

83. Yao, Z.T.; Xia, M.S.; Sarker, P.K.; Chen, T. A review of the alumina recovery from coal fly ash, with a focus in China. Fuel 2014, 120, 74-85. [CrossRef] 